\title{
Spatial and temporal patterns of urea content in a eutrophic stream continuum on the Northern Great Plains
}

\author{
Vanessa J. Swarbrick $\mathbb{D} \cdot$ Nathanael T. Bergbusch $\mathbb{D} \cdot$ Peter R. Leavitt $\mathbb{C}$
}

Received: 21 April 2021/Accepted: 4 October 2021/Published online: 21 October 2021

(C) The Author(s) 2021

\begin{abstract}
Urea can degrade water quality and stimulate toxic phytoplankton in P-rich lakes, yet little is known of its sources, abundance, or transportation in lotic systems, particularly within the Northern Great Plains. We measured physico-chemical parameters biweekly during May-September 2010-2012 at 16 stations along a $250 \mathrm{~km}$ lotic continuum to quantify spatial and temporal variation in urea concentrations and discharge, and to identify potential regulatory processes. Urea concentrations were similar to those in
\end{abstract}

Responsible Editor: Jennifer Leah Tank.

Supplementary Information The online version contains supplementary material available at https://doi.org/10.1007/ s10533-021-00868-7.

V. J. Swarbrick · N. T. Bergbusch · P. R. Leavitt ( $\square)$ Limnology Laboratory, Department of Biology, University of Regina, Regina, SK S4S 0A2, Canada e-mail: Peter.Leavitt@uregina.ca

Present Address:

V. J. Swarbrick

Alberta Environment and Parks, Edmonton,

AB T6B 2X3, Canada

Present Address:

N. T. Bergbusch

School of Environment, Resources and Sustainability, University of Waterloo, Waterloo, ON N2L 3G1, Canada

P. R. Leavitt

Institute of Environmental Change and Society, University of Regina, Regina, SK S4S 0A2, Canada regional prairie lakes (range 5.2-792.1, median $78.6 \mu \mathrm{g} \mathrm{N} \mathrm{L}^{-1}$ ) with variable seasonal mean $( \pm \mathrm{SD})$ concentrations $\left(96.6 \pm 96.1 \mu \mathrm{g} \mathrm{N} \mathrm{L}^{-1}\right)$ and fluxes $\left(4.22 \times 10^{5} \pm 257.6 \mu \mathrm{g} \mathrm{N} \mathrm{s}^{-1}\right)$. Landscape analysis with generalized additive models explained $68.3 \%$ of deviance in urea concentrations, with high temporal variability predicted mainly by positive relationships with nutrient content and chlorophyte abundance, but not temperature, dissolved organic matter, bacterial abundance, or urban effluent. Seasonal analysis revealed that during spring, urea content was correlated negatively with leguminous forage cover (\% area) and positively with stream discharge, oilseed and cereal crops, and shrubs or deciduous plants, while during summer, urea concentrations were correlated negatively with discharge and leguminous crop cover, as well as nutrient levels. Mean porewater urea concentrations $\left(528.5 \pm 229.8 \mu \mathrm{g} \mathrm{N} \mathrm{L}^{-1}\right)$ were over five-fold greater than stream concentrations, suggesting that hyporheic production may offset declining influx from terrestrial sources during summer. We conclude that urea may be ubiquitous in eutrophic prairie streams and that management of its export from land may reduce detrimental effects on downstream lakes.

Keywords Urea $\cdot$ Stream $\cdot$ Prairie $\cdot$ Eutrophic . Nitrogen · Agriculture · Urban · Effluent · Hyporheic · Qu'Appelle River 


\section{Introduction}

Dissolved organic nitrogen (DON) is increasingly recognized for its role in lotic nitrogen $(\mathrm{N})$ cycles and its impacts on water quality (Berman and Bronk 2003; Wiegner et al. 2006; Stanley and Maxted 2008) in lake (Berman 2001; Berman and Bronk 2003; Belisle et al. 2016) and coastal ecosystems (Seitzinger and Sanders 1997; Anderson et al. 2008; Korth et al. 2011). Of the diverse forms of DON, urea has received recent attention (Glibert et al. 2006; Solomon et al. 2010), as it is the most widely-used N-based fertilizer (Glibert et al. 2006) and has been linked to the proliferation of harmful algal blooms (Bogard et al. 2020; Swarbrick et al. 2020). Indeed, experimental fertilization with urea increases phytoplankton abundance in phosphorus (P)-rich systems by $400 \%$ (Finlay et al. 2010; Donald et al. 2011; Bogard et al. 2020), and selectively stimulates toxic cyanobacteria (Solomon and Glibert 2008; Donald et al. 2010; Solomon et al. 2010). The effects of urea pollution are of particular concern in the Northern Great Plains (NGP), where the compound comprises $>70 \%$ of N-based agricultural fertilizers (Statistics Canada 2016) and may be exported to P-rich downstream lakes (Bernot and Dodds 2005; Johnson et al. 2013; Rattan et al. 2016). Despite forecasts that urea supply rates from agriculture and urban sources will double by 2050 (Millennium Ecosystem Assessment 2005), little is known about the transport of urea from watersheds to downstream aquatic environments, particularly in the NGP.

While prior research on export of urea from watersheds to aquatic ecosystems has been limited mainly to temperate regions (Glibert et al. 2005; Han et al. 2015; Jackson 2016; Kibet et al. 2016; King et al. 2017), there are several reasons to expect that fluxes to freshwaters may be particularly elevated in the grassland environments of the NGP. First, these prairie watersheds include a variety of urea sources, including fertilizer applications (Davis et al. 2016; Kibet et al. 2016), intensive livestock operations (Peterson et al. 2004; Kibet et al. 2016), and urban effluents (Glibert et al. 2006; Bogard et al. 2012; Cozzi et al. 2014). Second, application rates of urea in the NGP are substantially elevated compared to other farming regions where urea export to streams has already been demonstrated (Belisle et al. 2016; Statistics Canada 2016). Third, the timing of urea application in NGP (spring, fall) is concurrent with hydrologic and meteorological conditions that may favor urea runoff (Stepanauskas et al. 2000; Siuda and Chróst 2006; Thorén 2007; Solomon et al. 2010). For example, spring snowmelt accounts for over $75 \%$ of annual hydrological runoff in Canadian Prairies (Pomeroy et al. 2007), as well as up to $\sim 80 \%$ of annual total nitrogen (TN) export to surface waters (Cade-Menum et al. 2013; Corriveau et al. 2013; Rattan et al. 2016). Further, cool temperatures in spring and fall can suppress enzymatic hydrolysis of urea to ammonium $\left(\mathrm{NH}_{3} / \mathrm{NH}_{4}{ }^{+}\right)$and favour export of undegraded molecules (Therkildsen and Lomstein 1994; King et al. 2017). Fourth, chemical inhibitors of urease are usually co-applied with urea to delay hydrolysis up to several weeks (Olson-Rutz et al. 2009), resulting in transport of undegraded urea to downstream ecosystems (Kibet et al. 2016). Together these findings suggest that streams of the NGP may exhibit particularly elevated concentrations and fluxes of urea during spring.

Urea concentrations within streams may also be regulated by in situ processes including production, transformation of nitrogenous compounds, and microbial uptake. For example, urea may arise from autochthonous sources including heterotrophic mineralization of particulate- and dissolved- organic $\mathrm{N}$ (PON, DON) within surficial sediments and water columns (Therkildsen and Lomstein 1994; L'Helguen et al. 2005; Thorén 2007; King et al. 2017), regeneration by suspended and benthic invertebrate grazers (Slawyk et al. 1998; Lomas et al. 2002; L'Helguen et al. 2005), photo-degradation of PON and DON (Bushaw et al. 1996; Bronk et al. 2010), and excretion from primary producers (Solomon et al. 2010). Such autochthonous urea production may be offset by heterotrophic and autotrophic microbial consumption, or by deposition as colloids or adsorbed onto particles. As well, the role of microbial consumption varies across environmental conditions, with potentially high rates of uptake by both heterotrophic microbes (Park et al. 1997; Jørgensen 2006) and autotrophs (Mitamura et al. 2000, 2012; Thorén 2007; Solomon et al. 2010; Donald et al. 2011; Bogard et al. 2020; Swarbrick et al. 2020). An integrated understanding of how these processes interact along lotic continua and across seasons is needed to assess the cumulative risks of urea pollution to surface water quality.

While dissolved inorganic nitrogen (DIN) export is well characterized (Mulholland 1992; Mulholland et al. 
2000; Peterson et al. 2001; Seitzinger et al. 2002), less is known about the factors which regulate spatial and temporal patterns of DON and urea in lotic systems (Brookshire et al. 2005; Lutz et al. 2011; Johnson et al. 2013; Wymore et al. 2015; Pennino et al. 2016). Prior research shows that landscape patterns of DON are affected by regional and local land-use activities (Wiegner et al. 2006; Scott et al. 2007; Stanley and Maxted 2008), although few studies explicitly target transport of urea. Some conceptual models suggest that lotic ecosystems may act like an "inert pipe" when export is controlled primarily by hydrologic conditions (del Giorgio and Pace 2008). Under these conditions, urea concentrations may increase with catchment area and distance downstream. Alternately, lotic ecosystems may act as "reactors" (del Giorgio and Pace 2008; Kaushal et al. 2014), wherein metabolic processes are controlled by variation in biotic and physico-chemical conditions (Wiley et al. 1990; Young and Huryn 1996), as well as the degree of coupling of biogeochemical cycles of carbon (C), N and phosphorus (P) (Brookshire et al. 2005; Lutz et al. 2011; Wymore et al. 2015). In this case, concentrations of DON may either decrease if selectively consumed (e.g., 'Passive Carbon Vehicle Hypothesis'; Brookshire et al. 2005; Wymore et al. 2015) or may increase if DIN is preferred over DON by microbes (e.g., 'DON Release Hypothesis'; Lutz et al. 2011). Irrespective of the precise formulation, these models all suggest that urea export will be influenced by biological, physical and chemical gradients in both terrestrial and aquatic environments, as well as how these factors interact in time and space.

Here we collected stream samples every second week during May to September at 16 sites to quantify spatial and temporal patterns of urea concentration along a 250-km continuum of eutrophic prairie streams. Our study area spanned a gradient of agricultural and urban land use, enabling evaluation of the influence of both diffuse inputs from the watershed and point-source inputs from urban effluent. Our primary goal was to quantify the spatial (landscape) and temporal (seasonal) patterns of urea concentration and flux in grassland streams. Second, we sought to identify the relative importance of potential hydrologic, land use, and in-stream processes as controls of variation in urea concentration. We hypothesized that urea concentrations and fluxes would increase along the continuum (Heathwaite and Johnes 1996), but that concentrations would be low compared to those in regional lakes where sediments are a major source of urea to the water column (Bogard et al. 2012). Further, we hypothesized that urea concentrations would be highest during spring, when discharge and runoff is high (Martin and Harrison 2011; Corriveau et al. 2013; Rattan et al. 2016), temperatures are cool, and agricultural practices (fertilization, urease inhibitor application) increase urea concentrations on land (Swensen and Singh 1997; Siuda and Chróst 2006; Solomon et al. 2010). Finally, we hypothesized that receipt of urban effluent from a tertiary wastewater treatment plant (WWTP) would increase urea concentrations, particularly during late summer (Bronk et al. 2010; Bogard et al. 2012; Cozzi et al. 2014) when base flow is low and effluent is a large fraction of stream discharge (Bergbusch 2020).

\section{Methods}

Study area

The study area is centred within the Qu'Appelle River catchment, a region which comprises over $52,000 \mathrm{~km}^{2}$ of mixed-grass prairie in southern Saskatchewan, Canada (Fig. 1). Wascana Creek is a first-order eutrophic stream that drains $\sim 1400 \mathrm{~km}^{2}$ of farmland before joining the main stem of the Qu'Appelle River. The headwaters of Wascana Creek are ephemeral, cease flow by mid-late summer, and empty into shallow Wascana Lake within the City of Regina. Below that point, Wascana Creek flows continuously, in part due to influx of tertiary-treated effluent (low $\mathrm{P}$, elevated N) from the City of Regina (Waiser et al. 2011; Bergbusch 2020). Flow is also continuous in the Qu'Appelle River, which originates upstream of eutrophic Buffalo Pound Lake, and flows eastward to Pasqua Lake following its confluence with Wascana Creek (Fig. 1). The natural flow of the Qu'Appelle River is managed, with augmentation of discharge from Buffalo Pound Lake, and late-summer inputs from sub-saline Last Mountain Lake just east of the Qu'Appelle-Wascana confluence. Further details of system hydrology are provided by Haig et al. (2020).

Regional climate is characterized as cool-summer humid continental (Köppen D $f b$ classification), with short summers (ca. June-August; mean $19{ }^{\circ} \mathrm{C}$ in July), cold winters (ca. November-February; mean $-16^{\circ} \mathrm{C}$ in January), and low annual temperatures $\left(\sim 2{ }^{\circ} \mathrm{C}\right)$ 


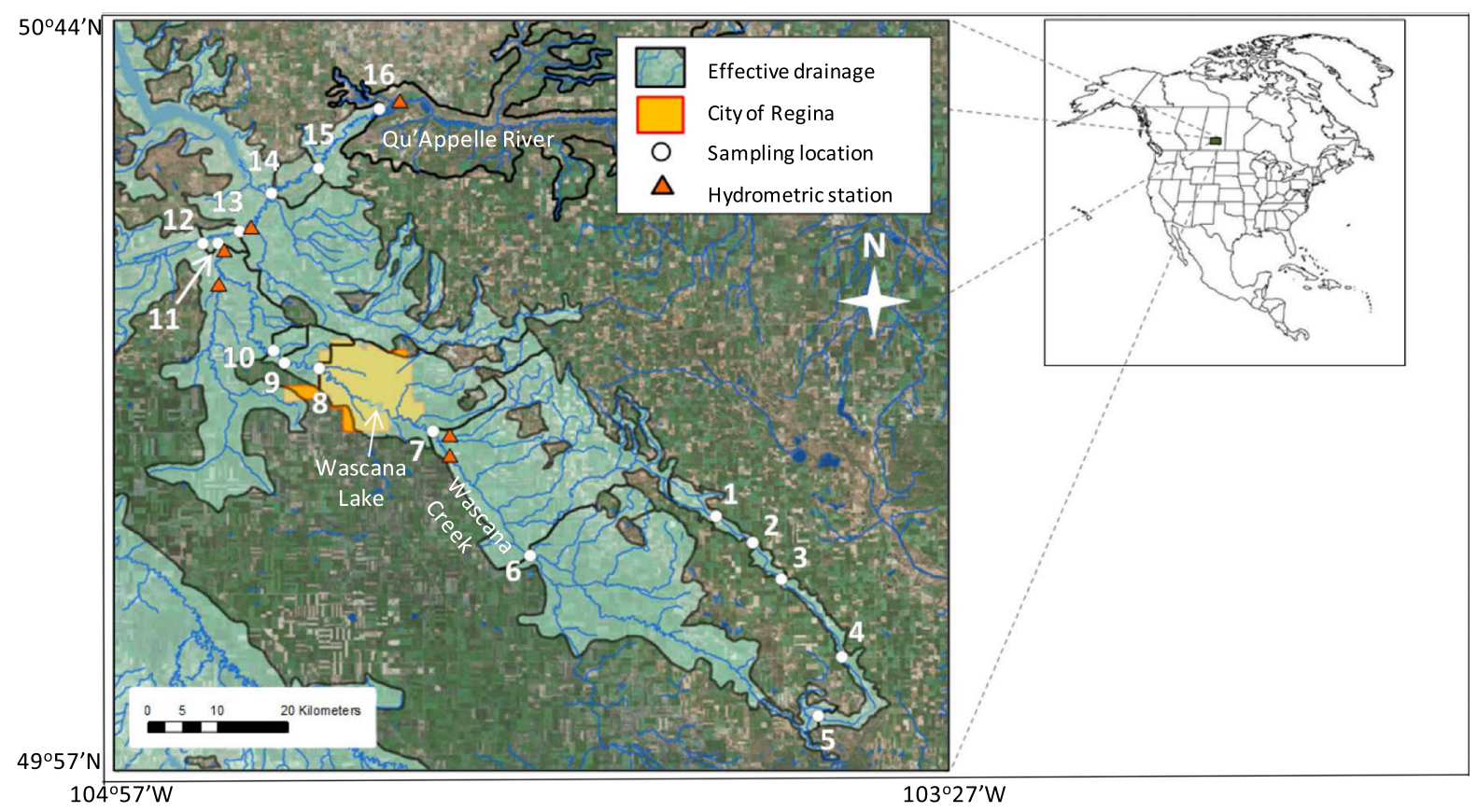

Fig. 1 Map of the study area within the Wascana Creek and lower Qu'Appelle River drainage basins in southern Saskatchewan, Canada. The 16 sample sites (white circles) are numbered in increasing order from headwaters to downstream, with sites 1-11 located along Wascana Creek and sites 12-16 along the

with high seasonal variability (Leavitt et al. 2006; Haig et al. 2020). Average annual precipitation is $~ 380 \mathrm{~mm}$ of which $\sim 30 \%$ falls as snow during the winter months (Pomeroy et al. 2007). Spring snowmelt, which typically occurs while soils are frozen during late March to early May, accounts for $>70 \%$ of annual surface runoff (Fang et al. 2007; Dumanski et al. 2015). In contrast, rainfall occurs primarily in spring and early summer and decreases towards fall, causing low soil moisture and very low runoff by late summer (Pomeroy et al. 2007). In recent years, summer precipitation has accounted for an increased fraction of inflow to lakes in the Qu'Appelle River chain, in part due to declining snowfall (Vogt et al. 2018; Haig et al. 2020).

Land use within the study area is characterized by intensive agricultural development, wherein $95 \%$ of grassland has been converted to crop (dryland wheat, canola, mustard) or intensive livestock production (Hall et al. 1999). Wascana Creek receives stormwaters and wastewater effluent from the City of Regina (site 9 in Fig. 1; population 210 500), as well as diffuse nutrient runoff from feedlot operations and
Qu'Appelle River. Federal and provincial hydrometric stations are shown as orange triangles. The incremental effective drainage are of each site and the City of Regina are delineated in green and orange, respectively

golf courses. In many reaches, the riparian zones are degraded (Miki 2015), leading to designations of 'stressed' or 'impacted' for the lower Wascana Creek and Qu' Appelle River ecosystems (Davies and Hanley 2010).

Sixteen sampling sites were located along a $\sim 250 \mathrm{~km}$ lotic continuum formed from Wascana Creek headwaters to the main stem of Qu'Appelle River near Pasqua Lake (Fig. 1). Seven sites were located upstream of Wascana Lake, five were located between Wascana Lake and the creek's confluence with the Qu'Appelle River, and four were located downstream on the Qu'Appelle River. One additional site (site 12) was located on the Qu'Appelle River upstream of the confluence with Wascana Creek. In addition to the 16 sampling sites, six gauged hydrometric stations operated by Water Survey of Canada (WSC), which recorded or modeled instantaneous discharge $\left(\mathrm{m}^{3} \mathrm{~s}^{-1}\right)$, were located within the study area (Fig. 1). 
Field methods

Ten study sites were sampled bi-weekly between May and September of 2010-2012 (Supporting Information), while an additional six sites were added in 2011 and 2012 (Fig. 1; Supporting Information). Sites were sampled between 9:00 and 13:00 h. Samples were collected from each site as long as water was present, irrespective of discharge rates. Water temperature $\left({ }^{\circ} \mathrm{C}\right)$, dissolved oxygen $\left(\mathrm{mg} \mathrm{O}_{2} \mathrm{~L}^{-1}\right)$, conductivity ( $\mu \mathrm{S}$ $\mathrm{cm}^{-1}$ ), and salinity (ppm) were measured in the middle of the water column at the stream thalweg using a YSI Model $85 \mathrm{~m}$. Streamwater $\mathrm{pH}$ was measured at 5-cm depth using a calibrated handheld Oakton model $20 \mathrm{pH}$ meter. A 10-L whole-water sample was collected from each site at mid-column depth along the thalweg. In 2011 and 2012, sampling was expanded to include turbidity and sediment porewater collection. Turbidity was calculated as the average of three replicate measurements using a portable LaMotte Model 2020we Turbidimeter. Standard volumes of sediment were collected for porewater analysis by inserting a polycarbonate tube into soft submerged substrate in $\sim 0.25 \mathrm{~m}$ of water or at the deepest location. The proportion of substrate types was not recorded. After collection of a core with an undisturbed sediment-water interface, the overlying surface water was gently decanted, and the uppermost $15 \mathrm{~cm}$ of sediment transferred to a sterile Nasco Whirl-Pak ${ }^{\circledR}$, after which air was purged prior to being sealed. All water and sediment samples were kept on ice and returned to the laboratory for processing within two hours of collection.

\section{Laboratory methods}

Upon return to the laboratory, samples were filtered and preserved prior to analysis. Whole-water samples were filtered through $\mathrm{GF} / \mathrm{F}$ glass fiber (nominal pore size $1.2 \mu \mathrm{m})$ and membrane filters $(0.45-\mu \mathrm{m}$ pore) before being frozen prior to nutrient analysis. Particulate organic matter (POM) on GF/F filters was frozen until analysis for chlorophyll $a(\mathrm{Chl} a)$ and biomarker pigments by high performance liquid chromatography (HPLC) using standard methods (Leavitt and Hodgson 2001). Subsamples were also refrigerated for analysis of dissolved inorganic- (DIC) and dissolved organic carbon content (DOC). Additionally, $10 \mathrm{~mL}$ of whole water was transferred using sterile technique to
Vacutainer vials, preserved with $0.5 \mathrm{~mL}$ of Lugol's iodine solution, sealed and stored in the dark until analysis for microbial cell density the National Hydrology Research Institute (NHRI) in Saskatoon, Canada (see below). Porewater was extracted from sediment samples by centrifugation at $5000 \mathrm{rpm}$ for 5 min (di Bonito et al. 2008), and supernatant was filtered through a $0.45-\mu \mathrm{m}$ pore membrane filter, then frozen until analysis for nutrients.

Chemical analyses were conducted at the Institute of Environmental Change and Society following standard procedures. Nitrate $\left(\mathrm{NO}_{3}{ }^{-}\right)$and nitrite $\left(\mathrm{NO}_{2}{ }^{-}\right)$(hereafter reported as $\mathrm{NO}_{3}{ }^{-}$), ammonia $\left(\mathrm{NH}_{3}\right)$ and ammonium $\left(\mathrm{NH}_{4}{ }^{+}\right)$(hereafter reported as $\mathrm{NH}_{4}{ }^{+}$), total dissolved nitrogen (TDN), soluble reactive phosphate (SRP), and total dissolved phosphorus (TDP) were analyzed using a Lachat QuikChem 8500 FIA automated ion analyzer following standards methods (APHA-AWWA/WEF 1998). Dissolved urea concentrations were measured by the diacetyl monoxime method of Revilla et al. (2005), slightly modified by Bogard et al. (2012). DIC and DOC were analyzed using a Shimadzu 5000A total carbon analyzer according to Finlay et al. (2009). Phytoplankton abundance was estimated from the concentration of Chl $a\left(\mu \mathrm{g} \mathrm{L}^{-1}\right)$ using standard trichromatic spectrophotometric methods (Jeffrey and Humphrey 1975). Phytoplankton composition was estimated from calibrated, reversed-phase HPLC analysis of biomarker pigments (nmoles pigments $\mathrm{L}^{-1}$ ) for siliceous algae (fucoxanthin), chlorophytes (Chl b), total cyanobacteria (echinenone), and cryptophytes (alloxanthin) following Leavitt and Hodgson (2001). Bacterial cell density was measured according to Waiser and Robarts (2004), wherein bacteria were stained using 40, 6-diamidino-2-phenylindole (DAPI), filtered onto black, 0.2-mm cellulose nitrate filters, and enumerated at $100 \times$ magnification using an epifluorescence microscope.

Discharge rates and fluxes

Instantaneous discharge rate $(\mathrm{Q})$ at the wadeable sites (sites $1-5 ;<1.3 \mathrm{~m}$ depth) was calculated by multiplying the measured water velocities within crosssectional increments and their area, following the twopoint and 6/10th depth methods of Buchanen and Somers (1976). Instantaneous Q at the non-wadeable sites was either recorded by provincial or federal WSA 
hydrometric real-time gauging stations (Fig. 1), or calculated using the drainage area ratio method (Gianfagna et al. 2015). The drainage area ratio method involves adjusting the measured discharge rates from the nearest gauged station by an estimate of prorated discharge from the incremental effective drainage area (EDA) to the sampling site ( $\left.\mathrm{Q}_{\text {incremental }}\right)$, as well as any additional point source discharges or tributary inputs. The $\mathrm{Q}_{\text {incremental }}$ is calculated by multiplying the discharge rate at the nearest gauged station by the ratio of the EDA of the ungauged sampling site to EDA of the gauged site as,

$\mathrm{Q}_{\text {incremental }}=\mathrm{Q}_{\text {gauged }} \times\left(\mathrm{A}_{\text {incremental }} / \mathrm{A}_{\text {gauged }}\right)$

where $\mathrm{Q}_{\text {gauged }}$ is the measured instantaneous discharge at the gauged site, $\mathrm{A}_{\text {incremental }}$ is the EDA between the sampling site and the gauged site, and $\mathrm{A}_{\text {gauged }}$ is the EDA of the gauged site. Discharge rates calculated using the drainage area ratio method do not account for evaporative losses, groundwater inputs or losses, attenuation, or time of travel between gauged and ungauged sites, and are limited by the accuracy of measured EDA. Instantaneous Q was not calculated for site 14 , as the site receives variable and ungauged hydrologic input from Last Mountain Lake (Fig. 1). Although highly correlated (slope $=0.84, \mathrm{R}_{\text {adj- }}{ }^{2}$ $=0.856, P<0.0001$ ), discharge measurements from wadable sites underestimated values calculated from gauging station data by about $0.75 \mathrm{~m}^{3} \mathrm{~s}^{-1}$ at flows between 1 and $8 \mathrm{~m}^{3} \mathrm{~s}^{-1}$ (Bergbusch 2020). Finally, instantaneous nutrient fluxes were calculated as the product of the instantaneous $\mathrm{Q}$ and nutrient concentration.

Watershed characteristics and geographic data processing

The EDA of each sampling site was determined using the federal Agriculture and Agri-Food Canada (AAFC) Watersheds Project (2008) dataset. The AAFC dataset defines the EDA as the maximum area that could contribute runoff to an individual site during average hydrologic conditions (Mowchenko and Meid 1983), and provided delineated incremental EDAs for six of the study sites. Incremental EDAs for the remaining sites were delineated manually based upon the AAFC total EDA boundary layer, 1:50,000 topographic data, and 1:50,000 hydrologic data
(Natural Resources Canada 2016) using ESRI ArcGIS 10.1. Because of the confounding effects of control structures that release or retain water from upstream lakes to the Qu'Appelle River, delineated EDA measurements for statistical analysis were restricted to sites 1 to 11 .

Annual land cover within the study area was extracted from the AAFC Annual Crop Inventory (2013), which uses optical (Landsat-5, AWiFS, DMC) and radar (RADARSAT-2) imagery to classify land cover into 65 different feature classes with a $56 \mathrm{~m}^{2}$ (2010) or $30 \mathrm{~m}^{2}(2011,2012)$ spatial resolution. Annual land cover data within the total upstream EDA of each site were clipped from the AAFC dataset using ESRI ArcGIS 10.1. Once the individual feature classes within each EDA were extracted, they were aggregated into nine land cover classes (e.g., urban, pasture, crop type, natural vegetation, etc.).

\section{Numerical analyses}

Generalized additive models (GAMs; Wood et al. 2016) were used to estimate spatio-temporal trends in urea and its relationships to in-stream conditions. Models of urea concentration were fit with predictors including year, day of year (date hereafter), landscape position of the site (site hereafter), and in situ physicochemical parameters following Bergbusch (2020). Because GAMs capture both linear and non-linear relationships among variables (Pedersen et al. 2019), this analytical approach allows better estimation of trends in mean values and associated uncertainties. Herein range and null space of the smoothers' penalty matrices were fully penalized to perform variable selection, improve model fit and parsimony, and reduce potential concurvity of smooths (Marra and Wood 2011). We assessed basis size, dispersion of residuals, homogeneity of variance, and relationship between the observed and predicted response for all models to ensure model assumptions were not violated. Inference was based on tests for smooths and random effects developed by Wood (2013a, 2013b), plus the effective degrees of freedom of estimated smooth and model terms. Models were run in $\mathrm{R}$ (version 3.6.2; $\mathrm{R}$ Core Team 2019) using $m g c v$ (version 3.6.2) with residual marginal likelihood (REML) smoothness selection (Wood 2011; Wood et al. 2017). We assumed urea concentrations were gamma distributed (positive, continuous responses). 
Only variables that were collected in all three years were considered as predictors. Marginal smooths were visualized using ggplot 2 version 3.2.1 in R (Wickham 2016).

To additionally evaluate spatial and seasonal patterns of stream urea concentrations, data were aggregated by month and location. Sites were classified into one of three regions (Bergbusch 2020): headwaters, which comprised the reaches from the headwaters to the wastewater treatment facility (WWTP; sites 1-8); wastewater-impacted locations which included reaches from the WWTP to the confluence (sites 9-11), and; Qu' Appelle River sites, those immediately downstream of the confluence (sites 13-16). Urea concentrations were $\log _{10}(\mathrm{x}+1)$ transformed and tested for normality using a Shapiro-Wilk test. A twoway ANOVA was used to identify whether transformed urea concentrations differed between months or regions, and if there was an interaction between the effects of month and region on urea levels. The Durbin-Watson test was used to assess first-order autocorrelation and ensure that data met the assumptions of independence required for a two-way ANOVA, while the Levene's test was used to assess homoscedasticity. Paired t-tests on $\log _{10}(\mathrm{x}+1)$ concentrations of urea, $\mathrm{NH}_{4}{ }^{+}, \mathrm{NO}_{3}{ }^{-}$, and TDN at sites 9 and 10 were conducted to assess if the discharge of urban effluent had a significant effect on instream $\mathrm{N}$ concentrations. Finally, because instantaneous discharge data were not normally distributed and data transformations to meet normality were unsuccessful, a non-parametric Kruskal-Wallis test with post hoc Dwass-Steel-Chritchlow-Fligner test for pairwise comparisons was used to identify significant differences in discharge rates between months.

We evaluated monthly relationships between discharge rate and urea concentration using Spearman rank correlation, where the sign of the coefficient $\left(r_{s}\right)$ indicated whether hydrological flux appeared to enhance or dilute in-stream urea concentrations. The relationship between urea concentration and relative percent abundance of each land cover type was evaluated separately by month using Spearman rank correlation. The relative strength and direction of relationships between the selected instream water quality parameters and urea concentrations was then assessed using Spearman rank correlation. These tests were conducted in SYSTAT v. 13.0, except for
Spearman rank correlations, which were conducted in TIBCO Spotfire v. 7.0.

\section{Results}

Spatial and temporal patterns in $\mathrm{N}$ concentrations

On average $(\bar{x} \pm \mathrm{SD})$, urea comprised $8.0 \pm 10.3 \%$ of TDN concentrations and $19.5 \pm 20.1 \%$ of bioavailable $\mathrm{N}$ (i.e., sum of urea, $\mathrm{NH}_{4}{ }^{+}$, and $\mathrm{NO}_{3}{ }^{-}$), with mean concentrations $\left(96.6 \pm 96.1 \mu \mathrm{g} \mathrm{N} \mathrm{L}^{-1}\right)$ that were lower than those of either $\mathrm{NO}_{3}{ }^{-} \quad(851.4 \pm$ $\left.1101.1 \mu \mathrm{g} \mathrm{N} \mathrm{L}^{-1}\right)$ or $\mathrm{NH}_{4}^{+}(1499.9 \pm 4425.5 \mu \mathrm{g} \mathrm{N}$ $\mathrm{L}^{-1}$ ). The relative importance of urea to the dissolved $\mathrm{N}$ pool varied spatially, with low and similar concentrations of urea $\left(101.0 \pm 104.7 \mu \mathrm{g} \mathrm{N} \mathrm{L}^{-1} ; 27-39 \%\right.$ of bioavailable $\mathrm{N}), \mathrm{NH}_{4}^{+}\left(158.5 \pm 304.4 \mu \mathrm{g} \mathrm{N} \mathrm{L}^{-1}\right)$, and $\mathrm{NO}_{3}{ }^{-}\left(162.7 \pm 257.6 \mu \mathrm{g} \mathrm{N} \mathrm{L}^{-1}\right)$ in the headwater sites (Fig. 2a) but divergent downstream patterns. For example, influx of N-rich urban effluent had only a marginal effect on urea concentrations in May $\left(t_{4}=-3.214 ; p=0.03\right)$, and no significant effect in any other month $(p>0.05)$, whereas $\mathrm{NO}_{3}{ }^{-}$ concentrations increased by up to $600 \%$ in the wastewater-impacted reach wastewater input (Fig. 2a) particularly during May $\left(\mathrm{t}_{4}=-2.647 ; p<0.05\right)$ and August $\left(\mathrm{t}_{5}=-8.944, p<0.01\right)$, while $\mathrm{NH}_{4}{ }^{+}$concentrations increased by up to $6000 \%$ (all months significant, $p<0.01$ ) when comparing sites immediately upstream and downstream of the WWTP (Fig. 2a). Overall, mean ( \pm SD) urea concentrations in sediment pore waters $\left(528.5 \pm 229.8 \mu \mathrm{g} \mathrm{N} \mathrm{L}^{-1}\right)$ were consistently and substantially elevated compared to concomitant concentrations in the overlying water column $\left(96.6 \pm 96.1 \mu \mathrm{g} \mathrm{N} \mathrm{L}^{-1}\right)$, regardless of location along the stream continuum (Supporting Information Fig. S1).

Urea concentrations and discharge rates

Urea concentrations varied substantially within each sampling year at individual sites (Fig. 3), with a trend to increased levels during late summer in headwaters, and declines through the sampling period in several downstream Qu'Appelle River sites (Fig. 4a). Despite this pattern, mean urea concentrations were similar in all months (range 49.9-81.3 $\mathrm{g} \mathrm{N} \mathrm{L}^{-1}$ ), with slightly elevated landscape values in mid-summer. Similarly, 

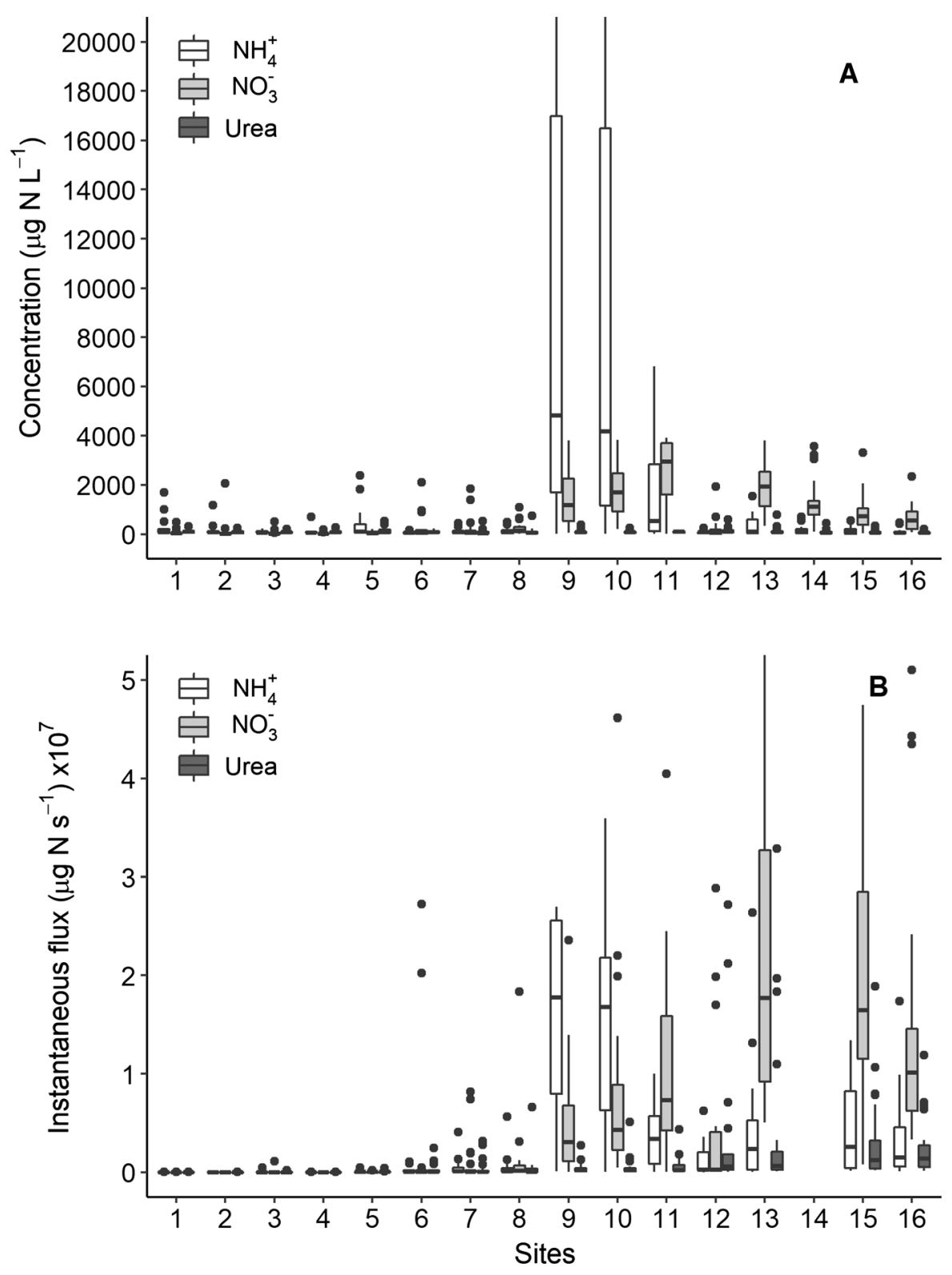

Fig. 2 a Average concentration $\left(\mu \mathrm{g} \mathrm{N} \mathrm{L}^{-1}\right)$ and $\mathbf{b}$ average instantaneous flux $\left(\mu \mathrm{g} \mathrm{N} \mathrm{s}^{-1}\right)$ of $\mathrm{NH}_{4}{ }^{+}, \mathrm{NO}_{3}{ }^{-}$, and urea at each site, between May and August of 2010, 2011, and 2012. Error

there were no significant differences $\left(\mathrm{F}_{(2,290)}=1.597\right.$, $p>0.05)$ in annual mean urea concentrations in headwater $\quad\left(66.1 \mu \mathrm{g} \mathrm{N} \quad \mathrm{L}^{-1}\right), \quad$ effluent-impacted (74.1 $\mu \mathrm{g} \mathrm{N} \mathrm{L}^{-1}$ ), and downstream Qu'Appelle River locations $\left(61.2 \mu \mathrm{g} \mathrm{N} \mathrm{L}^{-1}\right)$. In contrast, two-way ANOVA revealed a significant interaction between site location and month $\left(\mathrm{F}_{(6,290)}=8.183, p<0.001\right)$, consistent with the increase in urea concentration bars denote \pm 1 standard error. Note: fluxes are not calculated for site 14, as accurate discharge measurements were not available

through summer in headwaters, but not at downstream sites (Fig. 4a).

Instantaneous discharge rates (Figs. 2b, 4b) were significantly different among sampling months (Kruskal-Wallis test statistic $=30.61, p<0.01$ ), with pairwise comparisons and post hoc Dwass-SteelChrichlow-Fligner tests indicating that both May and June were significantly greater than other months, but 


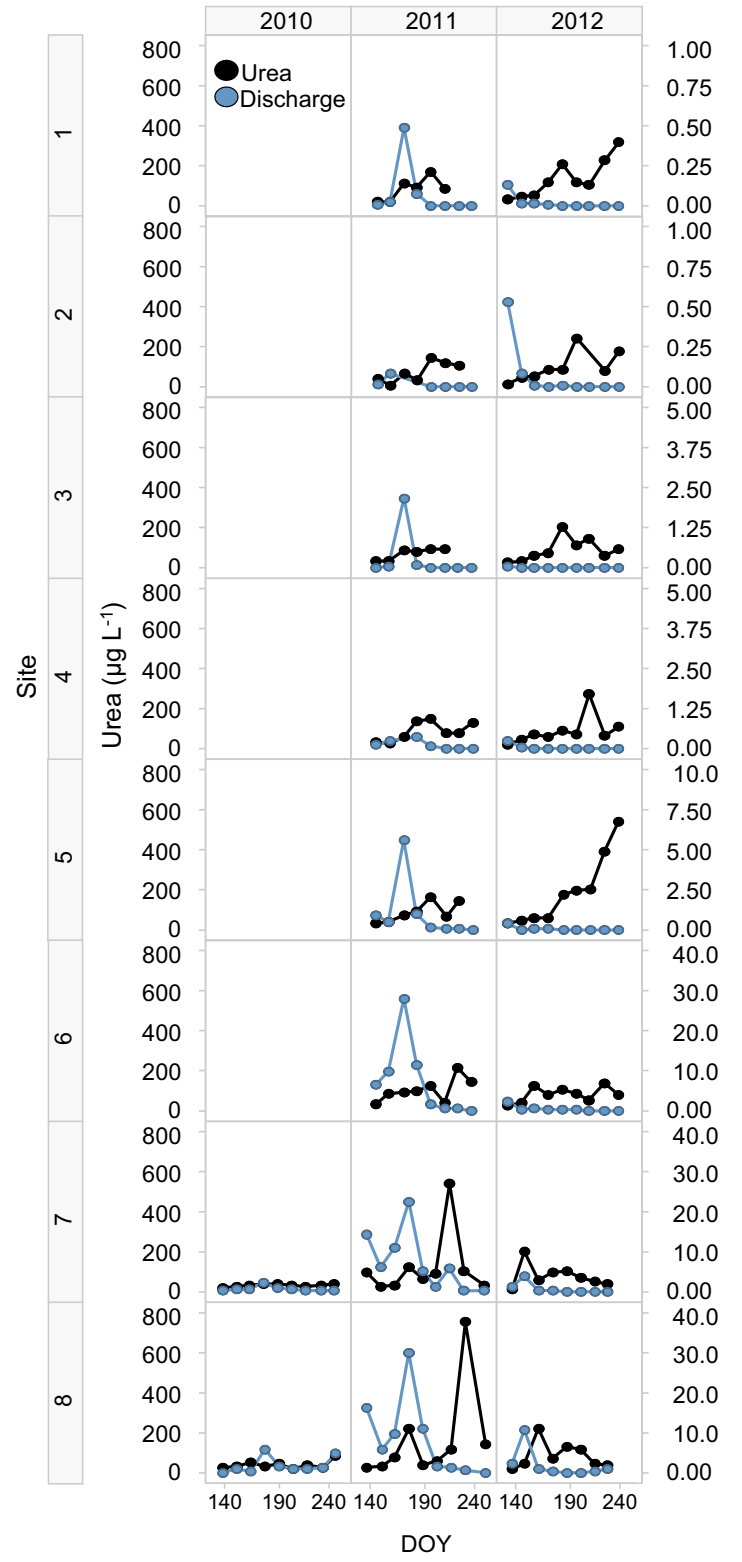

Fig. 3 Urea concentration $\left(\mu \mathrm{g} \mathrm{N} \mathrm{L}^{-1}\right)$ and instantaneous discharge rate $\left(\mathrm{m}^{3} \mathrm{~s}^{-1}\right)$ between May and September at each site, during 2010, 2011, and 2012. Columns represent sites

that July and August were similar (Supporting Information Fig. S2). Spearman rank correlations showed that although urea concentration and instantaneous discharge rate were not significantly related over the entire study period (Fig. 3; $\mathrm{r}_{\mathrm{s}}=-0.04, p=0.46$ ), they were significantly correlated within each month, though the direction of the relationship varied over the course of the sampling period (Supporting Information

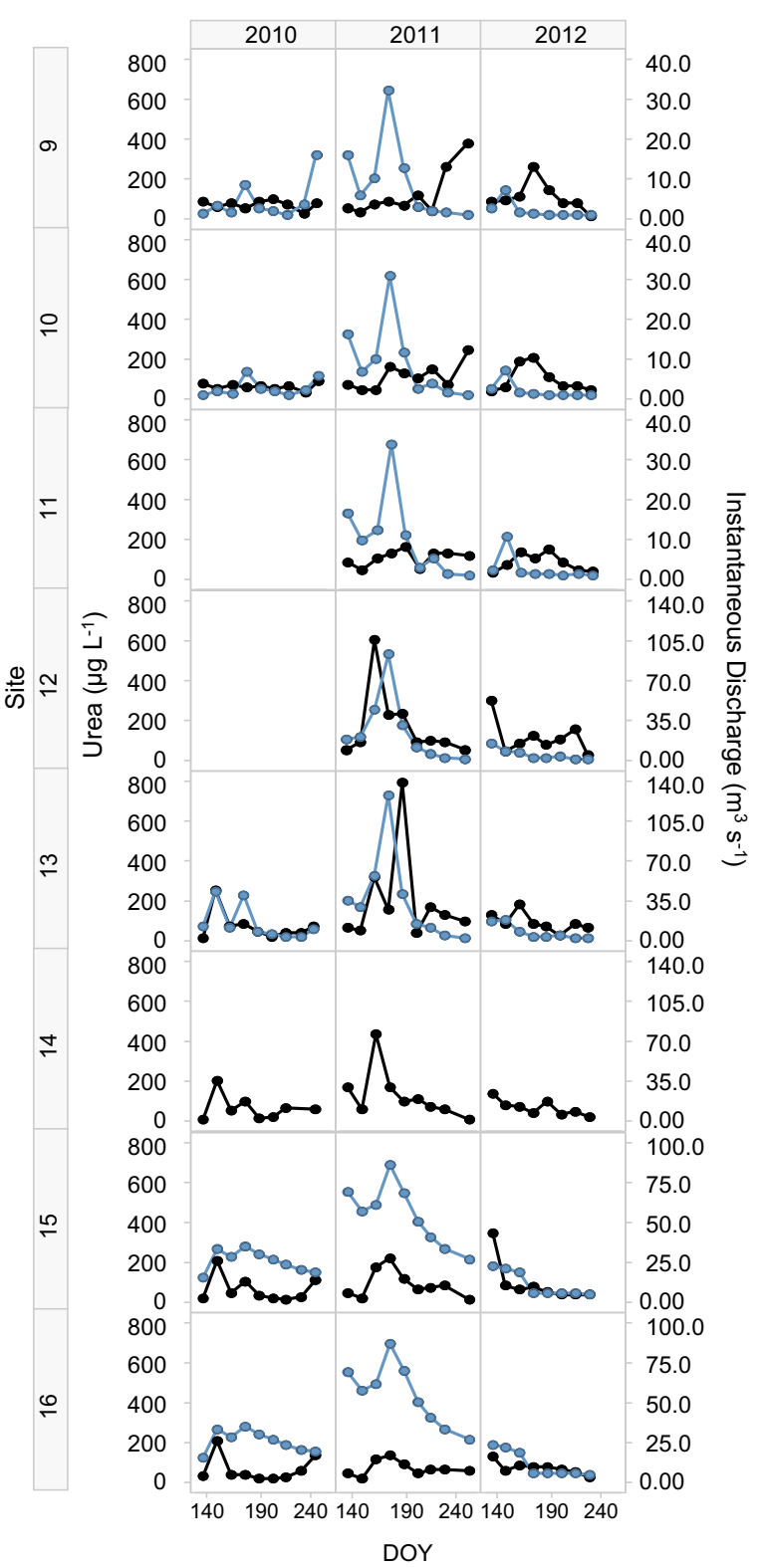

upstream (left, 1-8) and downstream (right, 9-16) of the City of Regina wastewater treatment plant

Fig. S4). Specifically, urea concentrations increased with discharge rates during May $\left(\mathrm{r}_{\mathrm{s}}=0.49, p<0.01\right)$ and June $\left(\mathrm{r}_{\mathrm{s}}=0.36, p<0.01\right)$, but declined with increased flows during July $\left(\mathrm{r}_{\mathrm{s}}=-0.45, p<0.01\right)$ and August $\left(\mathrm{r}_{\mathrm{s}}=-0.33, p<0.01\right)$, even though discharge was greater in the latter two months. 

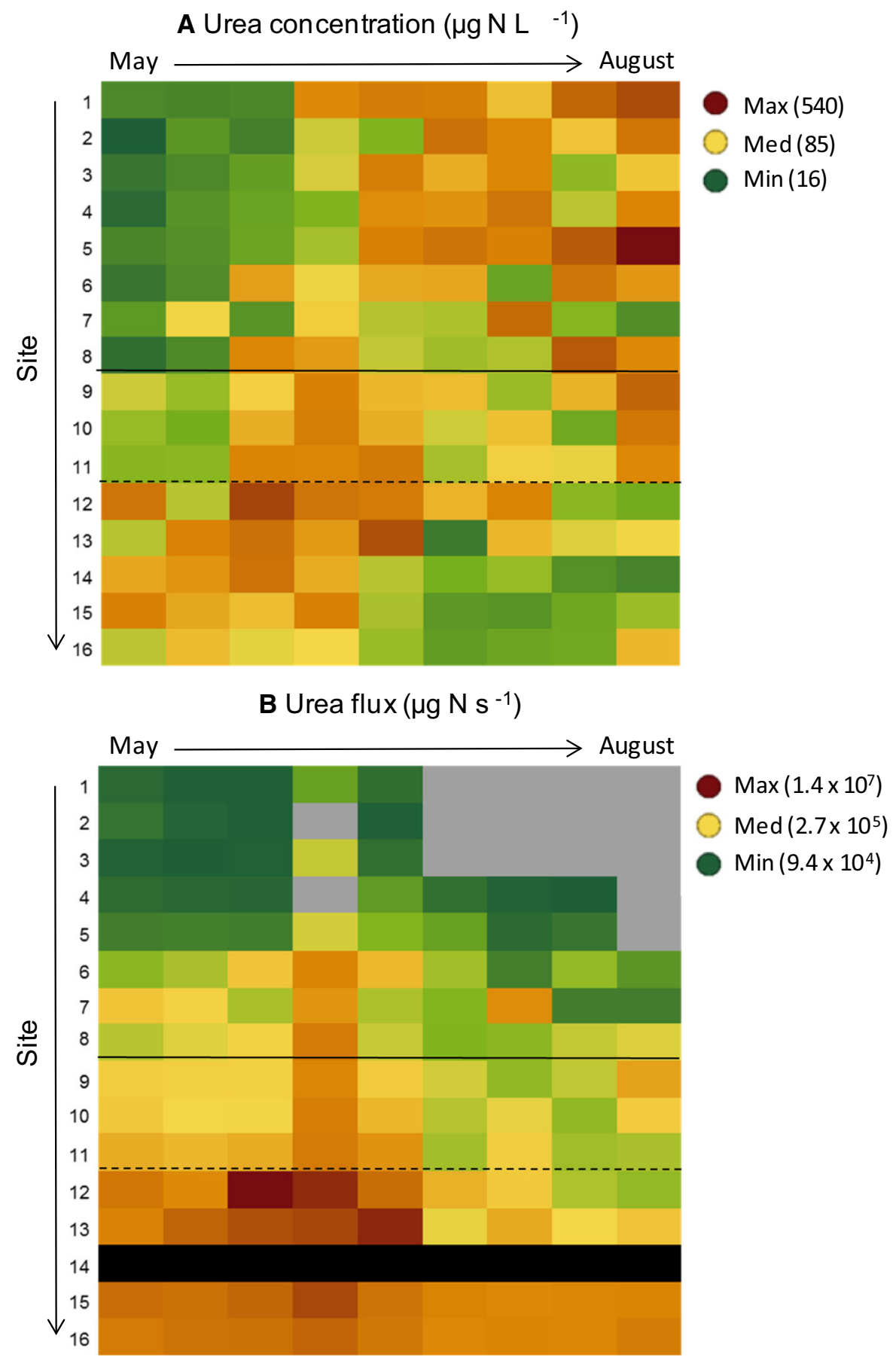

Fig. 4 Heat map of average bi-weekly (a) urea concentration $\left(\mu \mathrm{g} \mathrm{N} \mathrm{L}^{-1}\right)$ and $(\mathbf{b})$ instantaneous urea discharge rate $\left(\mu \mathrm{g} \mathrm{N} \mathrm{s}^{-1}\right)$ from May to September 2010, 2011, and 2012. Solid horizontal line represents location of the wastewater treatment plant, dashed line represents confluence of Wascana Creek and the Qu'Appelle River 
Fig. 5 Modelled marginal smooth effects of physico-chemical variables on in situ urea concentrations in Wascana Creek and the Qu'Appelle River during May-September 2010-2012. Generalized additive model explained $68.3 \%$ of deviance in landscape patterns of urea, with significant effects of (top to bottom) year, sampling date, discharge, specific conductance, nitrate $\left(\mathrm{NO}_{3}{ }^{-}\right)$, ammonium $\left(\mathrm{NH}_{4}{ }^{+}\right)$, soluble reactive phosphorus (SRP), total dissolved $\mathrm{N}$ to SRP ratios (TDN: SRP), and abundance of diatoms (fucoxanthin), chlorophytes (Chl b), cyanobacteria (echinenone) and total suspended phototrophs (Chl a). Solid lines represent the mean effect, while shaded areas indicate $95 \%$ credible intervals. Non-significant predictor variables are not presented, but include temperature, dissolved organic carbon, and bacterial abundance. Note that the y-axis is centred at zero, whereas the $\mathrm{X}$ axis varies with predictor. Ticks on $\mathrm{X}$-axis represent data observations

In situ correlates of urea concentration

Analysis using GAMs showed that overall urea concentrations were correlated strongly $(68.4 \%$ deviance explained) to variation in physico-chemical conditions, nutrient content, and autotrophic abundance (Fig. 5). Both year and sampling date were highly significant predictors, while sampling site was not an important variable influencing urea concentration. Urea concentration increased with year (not shown), and exhibited greatest levels during midsummer (Fig. 5a). Similarly, urea levels declined with specific conductance, showed complex relationships with discharge and DIC (Fig. 5a), but were uncorrelated to temperature, $\mathrm{DOC}, \mathrm{pH}$, and stream at the landscape scale. In general, urea levels increased significantly with concentrations of dissolved $\mathrm{NH}_{4}{ }^{+}$ and $\mathrm{NO}_{3}{ }^{-}$, but exhibited weak unimodal relationships $(p \sim 0.1)$ with SRP concentrations and TDP:SRP ratios. Among biotic predictors (Fig. 5c), urea content increased strongly with chlorophytes (as $\mathrm{Chl} \mathrm{b}$ ) and secondarily cryptophytes (as alloxanthin), declined slightly with elevated densities of cyanobacteria (as echinenone) and total phytoplankton abundance (Chl a), and were unrelated to densities of heterotrophic bacteria and hyporheic concentrations of urea (not shown).

Spatial and temporal patterns in nutrient fluxes

Mean fluxes of urea increased from headwaters to downstream sites (Fig. 2b) and, despite large seasonal changes in urea concentrations (Fig. 4a), were
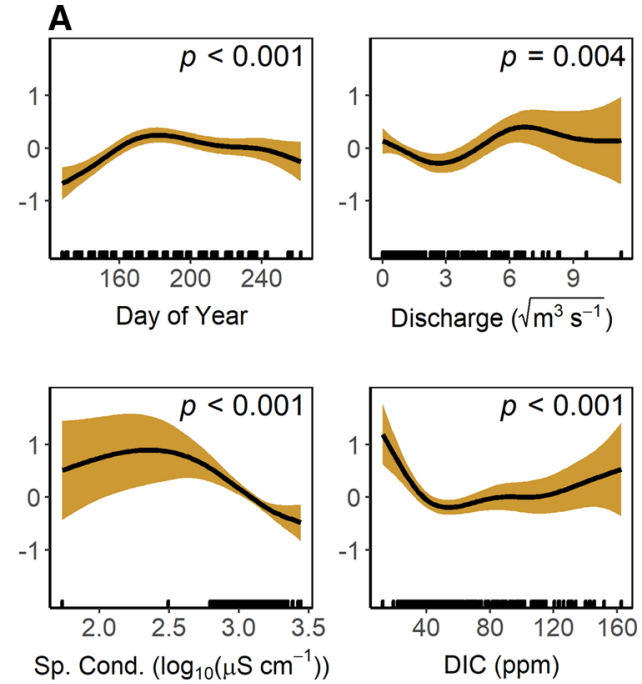

Sp. Cond. $\left(\log _{10}\left(\mu \mathrm{S} \mathrm{cm} \mathrm{cm}^{-1}\right)\right)$

B
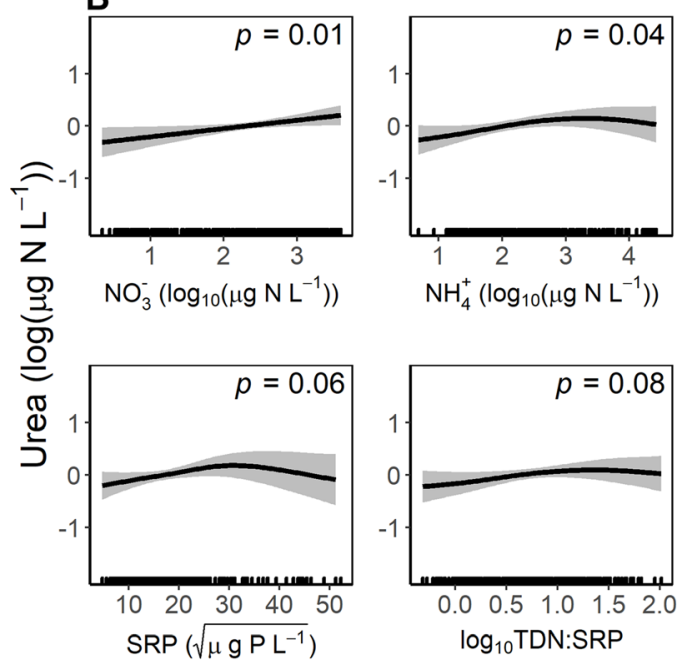

C
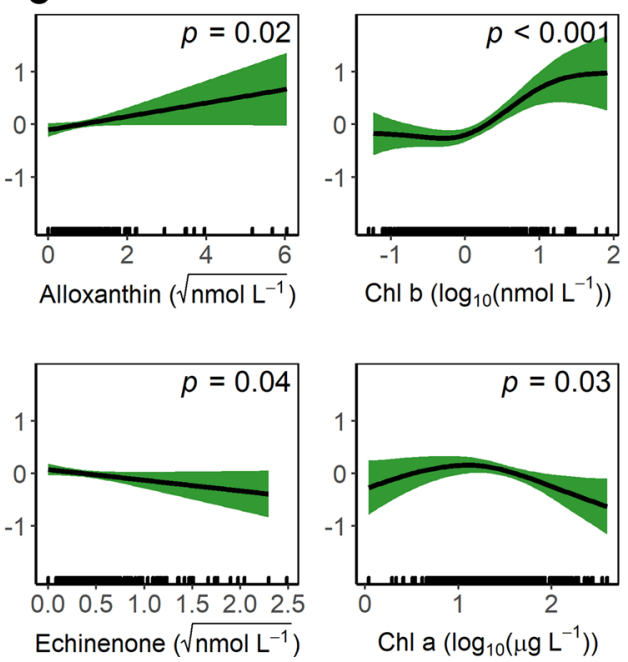
relatively consistent across the sampling period (Fig. 4b). Mean ( \pm SD) fluxes of urea $\left(4.22 \times 10^{5} \pm\right.$ $\left.257.6 \mu \mathrm{g} \mathrm{N} \mathrm{s}^{-1}\right), \quad \mathrm{NH}_{4}^{+} \quad\left(3.68 \times 10^{6} \pm 257.6 \mu \mathrm{g}\right.$ $\left.\mathrm{N} \mathrm{s}^{-1}\right)$, and $\mathrm{NO}_{3}^{-}\left(4.45 \times 10^{6} \pm 257.6 \mu \mathrm{g} \mathrm{N} \mathrm{s}^{-1}\right)$ were lowest in the upper headwaters (sites 1-5), and increased downstream, following patterns of stream discharge. Mean urea flux remained relatively consistent along Wascana Creek headwaters (sites 1-5), but increased downstream of Wascana Lake and, in particular, below the wastewater outfall point (site 9), where export increased by $450 \%$ relative to upstream samples. Despite this pattern, the greatest urea fluxes were recorded immediately above (site 12) and below the Wascana Creek-Qu'Appelle River confluence (site 13; Fig. 2b). In comparison, the largest increase in mean $\mathrm{NH}_{4}{ }^{+}$flux occurred immediately downstream of the wastewater treatment facility, with steadily declining values downstream of that point. Mean $\mathrm{NO}_{3}{ }^{-}$fluxes also increased below urban effluent outfall, but remained elevated downstream, with the largest fluxes observed downstream of the Qu'Appelle River confluence (Fig. 2b). As shown elsewhere, these patterns are consistent with intense microbial nitrification downstream of the wastewater treatment plant (Dylla 2019).

\section{Land use patterns}

Pasture and crops consistently had the highest relative (\%) cover within the EDA of each site (Fig. 6 a-c), whereas wheat (up to $66 \%$ cover), lentils (53\%), and canola $(41 \%)$ were the most common crops. The relative proportion of the aggregated land cover classes varied along the lotic continuum, with cereals, canola, and pasture dominating the headwater EDAs, whereas deciduous trees and shrubs increased in the downstream portions of the study area. In contrast, urban land was concentrated predominantly between sites 7 and 8, where it comprised $40 \%$ of incremental EDA. Relative proportion of land cover type also varied by year. For example, legumes dominated crop cover in 2010 (Fig. 6a), while a late spring and wet conditions in 2011 restricted crop production and increased the relative abundance of both surface water/wetlands (up to $32 \%$ ) and pasture (up to $43 \%$ ) within the watershed (Fig. 6b). Dry conditions in 2012 led to a greater abundance of cereal crops (Fig. 6c).
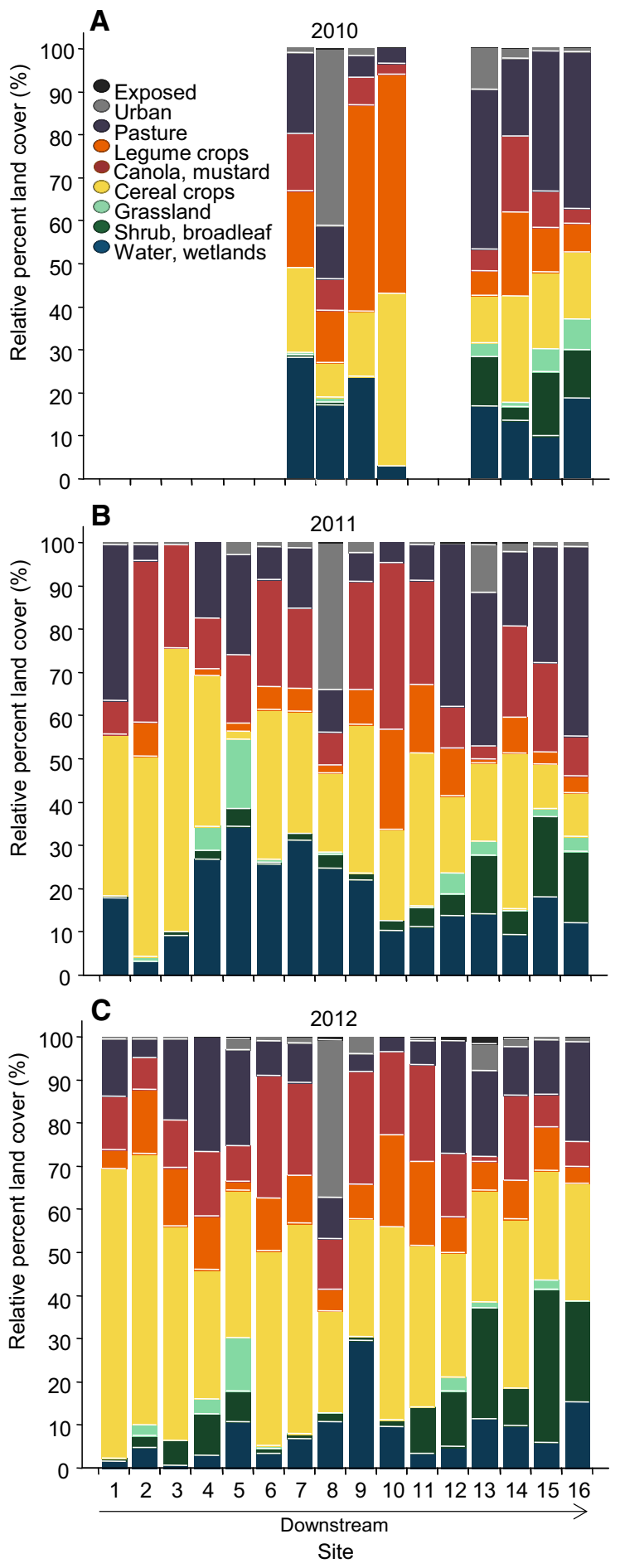

Fig. 6 Relative percent cover of each aggregated land cover type (see inset, panel a) within the total effective drainage area upstream of each sampling site in (a) 2010, (b) 2011, and (c) 2012 
Land use correlates of urea concentration

In-stream urea concentrations were correlated significantly to five of the nine aggregate land cover types, though relationships varied by month (Table 1). Significant positive correlations between relative abundance of canola and urea concentrations were observed in May and June $\left(\mathrm{r}_{\mathrm{s}}=0.31-0.52, p<0.05\right)$. June urea concentrations were correlated positively with cereals $\left(\mathrm{r}_{\mathrm{s}}=0.32, p<0.01\right)$, exposed land $\left(\mathrm{r}_{\mathrm{s}}=0.40, p<0.01\right)$, and shrub-deciduous cover $\left(\mathrm{r}_{\mathrm{s}}=0.36, p<0.01\right)$, and negatively to pastures $\left(r_{\mathrm{s}}=-0.30, p<0.05\right)$. Although cereal and shrub covers remained correlated positively to urea concentrations in July $\left(\mathrm{r}_{\mathrm{s}}=0.42, p<0.01\right)$, legume cover also predicted urea concentrations in July and August $\left(\mathrm{r}_{\mathrm{s}}=-0.27\right.$ to $\left.-0.51, p<0.05\right)$.

\section{Discussion}

Urea comprises $\sim 70 \%$ of nitrogenous fertilizer application in the Canadian Prairies (Glibert et al. 2006; Statistics Canada 2016), yet little is known of the patterns and controls of urea export to lotic ecosystems of the NGP. Unexpectedly, urea concentrations along the lotic continuum were elevated compared to those recorded in regional lakes (Finlay et al. 2009; Bogard et al. 2012). While urea fluxes remained relatively consistent through time at individual stations (Fig. 4b), two distinct longitudinal patterns in urea concentration emerged during the sampling period (Fig. 4a, Supporting Information Fig. S1), each mediated by interactions between hydrology, land use, and in situ stream processes. Consistent with our initial hypotheses, spring concentrations of urea increased along the continuum and were correlated positively to the relative abundance of $\mathrm{N}$-intensive crops within the upstream catchment, although only when runoff (Pomeroy et al. 2007) and agricultural fertilization applications are typically elevated (Cade-Menun et al. 2013). In contrast, urea concentrations during summer decreased with distance downstream and were inversely related to hydrologic fluxes, possibly reflecting offsetting dilution of elevated hyporheic sources of urea (Supporting Information Figure S1), as seen elsewhere (Thorén 2007; King et al. 2017). However, contrary to our second hypothesis, effluent discharge had no effect on urea unlike other nitrogenous compounds (Waiser et al. 2011; Bergbusch 2020). Instead, urea concentrations during summer were correlated positively with dissolved $\mathrm{N}$ concentrations $\left(\mathrm{NO}_{3}{ }^{-}, \mathrm{NH}_{4}{ }^{+}\right)$and abundance of chlorophyte algae, taxa which benefit from pollution with urban wastewater (Bergbusch 2020; Bogard et al. 2020). Given these patterns, and considering the detrimental effects of urea on water quality, cyanobacterial abundance, and toxicity (Donald et al. 2011; Krausfeldt et al. 2019; Swarbrick et al. 2020), our results suggest that surface water management in the NGP needs to consider lotic inputs of urea as a potential factor degrading prairie streams and lakes.

Urea concentrations compared to other lotic systems

Despite the widespread use of urea fertilizers (Glibert et al. 2006; Statistics Canada 2016), there is little empirical data on spatial and temporal variation in urea within lotic systems in agricultural regions. Urea concentrations in this study (range 5.2-792.1 $\mu \mathrm{g} \mathrm{N}$

Table 1 Spearman rank correlation coefficients $\left(r_{s}\right)$ between instream urea concentration and relative abundance of land cover type with the total upstream effective drainage area.

\begin{tabular}{|c|c|c|c|c|c|c|c|c|}
\hline Date range & Canola/Mustards & Cereals & Exposed & Grassland & Legumes & Pasture & Shrub/Deciduous & Urban \\
\hline All & & 0.23 & & & & & 0.21 & \\
\hline May & 0.31 & & & & & & & \\
\hline June & 0.52 & 0.32 & 0.40 & & & -0.30 & 0.36 & \\
\hline July & & 0.42 & & & -0.27 & & 0.27 & \\
\hline August & & & & & -0.51 & & & \\
\hline
\end{tabular}

Only significant $(\mathrm{p}<0.05)$ or highly significant $(\mathrm{p}<0.01$ in bold) correlations are shown 
$\mathrm{L}^{-1}$; mean 60-90 $\left.\mu \mathrm{g} \mathrm{N} \mathrm{L}^{-1}\right)$ were generally elevated relative to values reported for boreal $(<39.5 \mu \mathrm{g} \mathrm{N}$ $\mathrm{L}^{-1}$; Stepanauskas et al. 2000), temperate $(<54 \mu \mathrm{g} \mathrm{N}$ $\mathrm{L}^{-1}$; Glibert et al. 2005; Tzilkpwski et al. 2018), and subtropical lotic ecosystems ( 20-160 $\mu \mathrm{g} \mathrm{N} \mathrm{L}^{-1}$; Han et al. 2014), as well as rivers receiving nutrients from industrial $\left(<124 \mu \mathrm{g} \mathrm{N} \mathrm{L}^{-1}\right.$; Remsen et al. 1972), urban $\left(<83.4 \mu \mathrm{g} \mathrm{N} \mathrm{L}^{-1}\right.$; Mitamura et al. 1994), or agricultural sources $\left(<220 \mu \mathrm{g} \mathrm{N} \mathrm{L}{ }^{-1}\right.$; Tzilkowski et al. 2018). Instead, intensive sampling during the open-water seasons 2010-2012 demonstrated that undegraded urea was ubiquitous and important, comprising up to $40 \%$ of bioavailable dissolved $\mathrm{N}(19.5 \pm 20.1 \%)$ and nearly $20 \%$ of TDN $(8 \pm 10.3 \%)$ in two eutrophic streams of the Canadian Prairies.

Longitudinal patterns in urea along the lotic continuum

Downstream patterns of urea concentration were the product of complex interactions between allochthonous and autochthonous inputs, biological processing, and in situ physico-chemical conditions. Although urea concentrations can increase downstream in large, coupled, lentic-lotic systems (Bogard et al. 2012), longitudinal patterns of urea recorded here varied among seasons, with urea concentrations increasing from first-order headwaters to downstream sites during spring and early summer, but decreasing along the continuum during mid- to late summer (Fig. 4), resulting in little spatial pattern at the annual scale (Fig. 5). As seen elsewhere for TN and DON (Martin and Harrison 2011; Corriveau et al. 2013; Rattan et al. 2017), lotic urea concentrations during spring appeared to be mediated mainly by high runoff that exported urea from terrestrial sources (Table 1). We hypothesize that agricultural fertilization in spring, often used in combination with urease inhibitors (Malhi et al. 2003), may combine with seasonally elevated runoff (Pomeroy et al. 2007) and lower temperatures to favour export of undegraded urea from agricultural fields or unimproved lots (Table 1) and that these inputs should increase as a function of the total drainage area. In contrast, the downstream decline in urea concentrations during summer (Fig. 4a) may reflect offsetting effects of elevated hyporheic influxes at all sites (Supporting Information Fig. S1), combined with progressive increases in stream flow (minimal in headwaters) that dilute in situ urea concentration (Fig. 4a) while maintaining overall high rates of export (Figs. 2b, 4b).

\section{Correlates of urea concentrations}

GAM analysis of landscape patterns of urea concentration suggest a paramount effect of seasonality, discharge, conductivity, in situ nutrient content, and chlorophyte biomass on water column levels of urea (Fig. 5). However, unlike most of the dissolved nutrient and biological predictors, variation in physico-chemical conditions appeared to have complex, non-linear relationships with in-stream urea content when analyzed over three years and 16 sites. As noted below, non-parametric analysis of individual months reveals pronounced differences in predictive models among seasons (Supporting Information Fig. S4) and suggests that some of the non-linearity in responses arises from changes in regulatory mechanisms among seasons.

Spring-Unlike previous studies that observed positive relationships between agricultural land use and DIN content in prairie surface waters (Corriveau et al. 2013), we found that urea concentrations were only correlated positively to agricultural land cover during spring and early summer (Table 1). Here, elevated urea levels occurred concomitant with seasonal maxima in runoff (Pomeroy et al. 2007; Pham et al. 2009; Fig. 3) and increased inputs of allochthonous nutrients, similar to patterns seen for vernal DON export elsewhere (Stepanauskas et al. 2000; Siuda and Chróst 2006; Martin and Harrison 2011; Tzilkowski et al. 2018), particularly in regions experiencing intensive agriculture (Pellerin et al. 2006; Johnson et al. 2009). In addition to vernal inputs, relationships between urea and in situ variables indicate that urea was subject to only minor processing during May and June. For example, the observed relationships between urea, DOC and $\mathrm{NO}_{3}{ }^{-}$were most consistent with predictions of the "DON release hypothesis" (Lutz et al. 2011; Wymore et al. 2015), wherein DIN is preferred by microbes over DON when DOM pools are sufficient. Specifically, the DON release hypothesis predicts that DON concentrations will increase with distance downstream, such as seen here in spring (Fig. 4a).

Elevated urea concentrations in prairies streams during May and June coincide with high relative 
abundance of canola and other oilseed crops (Table 1), similar to temporal patterns of DON content seen elsewhere (Kemp and Dodds 2001; Pellerin et al. 2006; Johnson et al. 2009; Kaushal et al. 2014). Not only do these crops have elevated $\mathrm{N}$ demand that is met by fertilization (McKenzie et al. 2004), but, unlike cereal crops, oilseeds often have a "memory effect" on nutrient export (Heathwaite and Johnes 1996), wherein leaves and residues continue to release DON even after harvest. Further, the most common canola production practices involve broadcast application of urea, with urease inhibitors or polymer coatings, prior to or during peak hydrologic runoff in spring and fall (Olson-Rutz et al. 2009) or shortly before rainfall events or irrigation to prevent degradation to $\mathrm{NH}_{3}$ and volatilization (Thiessen et al. 2005; Kibet et al. 2016). In contrast, inverse relationships between in-stream urea concentrations and the abundance of pasture land, which primarily comprises $\mathrm{N}_{2}$-fixing alfalfa and legume forages (Agriculture Canada 1982), are consistent with the low levels of $\mathrm{N}$ fertilizer applied to pastures. Given that global production of canola and oilseeds crops is projected to rise (Food and Agriculture Organization of the United Nations 2002), these results suggest that future management strategies should control urea export to protect downstream water quality.

Summer-Unlike prior studies of regional lake ecosystems (Bogard et al. 2012), summer urea concentrations did not increase markedly with drainage area. Instead, urea concentrations observed during July and August were inversely related to lotic discharge, but correlated positively to indicators of microbial abundance (e.g., chlorophytes), suggesting that urea levels were affected by a combination of in situ sources and biological transformations (Fig. 5). For example, longitudinal patterns showed that summer urea concentrations were highest in the headwaters, concurrent with elevated $\mathrm{Chl} a$ abundance, and declined downstream with increasing bacterial abundance (Supporting Information Fig. S4). These relationships are consistent with studies showing urea and DON uptake can be regulated by microbial activity (Cho et al. 1996; Park et al. 1997; Berman and Bronk 2003; Jørgensen 2006; Tzilkowski et al. 2018), and that DON can comprise $70-100 \%$ of TDN consumed by autotrophic and heterotrophic communities (Seitzinger and Sanders 1997; Wiegner et al. 2006). Additionally, low stream discharge during summer may enable longer contact between solutes and the streambed, thereby favouring both increased hyporheic loading and bacterial mineralization of urea (Therkildsen and Lomstein 1994; Park et al. 1997; Thorén 2007; King et al. 2017) relative to spring. The significant, but opposing, correlations of urea content with chlorophytes and cryptophytes (positive) and cyanobacteria (negative) (Fig. 5) also suggest that urea levels are regulated by the balance between production and consumption of urea by diverse photoautotrophs in lentic systems (Mitamura and Saijo 1980; Mitamura et al. 2000, 2012; Bronk et al. 2007; Solomon et al. 2010; Bogard et al. 2020). Taken together, these patterns are consistent with a presumptive shift in regulatory mechanisms from mainly physical controls of terrestrial runoff in spring to metabolic controls related to stream production in summer. This latter case is consistent with the "Passive C Vehicle" model (Brookeshire et al. 2005; Wymore et al. 2015), wherein the low C:N conditions characteristic of agricultural catchments (Heinz et al. 2015) favour preferential uptake of DON over DIN (Ghosh and Leff 2013).

Some land-use practices may continue to influence lotic urea concentration during summer (Table 1). For example, legume crops were correlated negatively with urea concentrations during July and August $\left(r_{\mathrm{s}}=-0.27\right.$ to $\left.-0.51, p<0.05\right)$, consistent with reduced fertilization of $\mathrm{N}_{2}$-fixing crops and their use in regional crop rotation to regenerate soil $\mathrm{N}$ content (Przednowek et al 2004). In contrast, cereal crops were positively related to urea concentrations in July, a period which coincides with the increased water requirements of the cereal flowering phase (Alberta Agriculture and Forestry 2011). Although rarer than in other agricultural regions, regional irrigation can be used to supplement late season water requirements for cereal crops in conjunction with $\mathrm{N}$ fertilization (Alberta Agricultural and Rural Development 2013), particularly within the Qu'Appelle River valley. Together, these results suggest that agricultural practices may influence urea concentrations summer-long, and that beneficial management practices and fertilizer management plans should consider the entire spring and summer period. 
Hyporheic urea sources

This study demonstrated that urea concentrations were greatly elevated within the hyporheic zone (Supporting Information Fig. S1), consistent with measurements of organic nitrogen concentrations in the hyporheic zone of other lotic ecosystems (Triska et al. 1990; Lorite-Herrera et al. 2009; Tzilkowski et al. 2018), and mass-balance models which propose that sedimentary urea is a key influx to prairie lakes (Bogard et al. 2012). Although correlations between water-column and porewater urea concentrations were not significant at the annual scale (Fig. 5) and varied markedly among seasons, mean concentrations within the hyporheic zone were five- to tenfold greater than those in the water column at all sites (Supporting Information Fig. S1). Based on the strong positive relationship between urea concentrations and the abundance of chlorophyte algae that predominate in regional benthic habitats (Bergbusch 2020), as well as the large pool of sedimentary urea, we speculate that water-column urea may originate mainly from hyporheic sources during summer (Therkildsen and Lomstein 1994; King et al. 2017; Tzilkowski et al. 2018). Future research should investigate this linkage, as well as that between the presence of phytobenthos (e.g., chlorophytes), urea production, and microbial consumption.

Effect of urban wastewater inputs on urea concentration

Contrary to our initial hypothesis and in contrast to studies in other regions (Cozzi et al. 2014; Mitamura et al. 1994; Switzer et al. 2008), there was no marked effect of urban effluent influx on urea concentrations under most hydrologic conditions. However, our findings are consistent with those of Bogard et al. (2012) who found that urea concentrations within Regina effluent were usually $<70 \mu \mathrm{g} \mathrm{N} \mathrm{L}^{-1}$, levels similar to those observed upstream of the wastewater treatment facility $\left(97 \pm 146 \mu \mathrm{g} \mathrm{N} \mathrm{L}^{-1}\right)$. We hypothesize that the low and similar concentrations of urea in urban effluent and headwater Wascana Creek may reflect the fact that the Regina WWTP used tertiary treatment processes in which DOM content was greatly reduced by microbial uptake during monthlong incubations in slow-flowing clarifier tanks. Instead, urban effluent may have exerted mainly indirect effects on urea content in eutrophic streams by altering the presence of nitrogenous chemicals and downstream biota (Bergbusch 2020) which subsequently affected urea concentrations (Fig. 5).

Implications for downstream water quality

This study suggests that land-use practices, in-stream conditions, and benthic processes interact to regulate the content and flux of urea through eutrophic streams of the NGP. However, the relative importance of these elements appeared to shift seasonally as hydrologic conditions changed, with the continuum acting as an "inert pipe", transporting increasing fluxes of urea downstream during the spring, but acting like a "reactor" during the summer (del Giorgio and Pace 2008). Overall, our findings suggest that there were few changes in mean monthly urea export to lakes during the study period, as elevated in situ production may have offset decreases in allochthonous sources and hydrological discharge. This finding contrasts extensive research which shows that most TN and DON is exported from prairie catchments during spring snowmelt (Corriveau et al. 2013; Martin and Harrison 2011; Rattan et al. 2016) and suggests that urea pollution may degrade downstream water quality in any season (Swarbrick et al. 2020).

Improved understanding of the processes regulating export of urea from agricultural catchments is critical for predicting its impacts on surface waters in the NGP. Previous mass-balance studies inferred that lotic ecosystems may not supply a high proportion of urea to lakes in the NGP (Bogard et al. 2012), whereas our study infers that flowing waters can provide an unexpectedly consistent supply of urea despite seasonal changes in hydrology, land-use practices, sources, and in situ processes. Given this observation, we suggest that development of nutrient objectives for urea may be an effective instrument to manage water quality (Chambers et al. 2011), particularly in the NGP where lotic $\mathrm{N}$ concentrations are elevated (Waiser et al. 2011), in situ $\mathrm{NH}_{4}{ }^{+}$and $\mathrm{NO}_{3}{ }^{-}$levels exceed federal chronic toxicity guidelines (CCME 2010, 2012), and P-rich lakes are degraded by N influx (Leavitt et al. 2006; Swarbrick et al. 2020). As agricultural production and fertilizer use is projected to double by 2050 (Millennium Ecosystem Assessment 2005), an increased focus on urea 
biogeochemistry may be essential to protect surface waters in the NGP.

Acknowledgements We thank members of the Limnology Laboratory for assistance with data collection, particularly J. Ziegler for stream sampling, M. Waiser and V. Tumber for microbial analyses, and IECS staff for support with water chemistry analyses. We thank the Water Survey of Canada and the Saskatchewan Water Security Agency for data on surface flow in the Qu'Appelle River drainage basin, K. R. Hodder for assistance with discharge calculations, K. Gallant at City of Regina for wastewater data, and D. Bateson for HPLC assistance. This work was supported by an NSERC Alexander Graham Bell Canada graduate scholarship, NSERC Canada Discovery Grants program, Canada Research Chairs, Canada Foundation for Innovation, the Province of Saskatchewan, and the University of Regina. Research was conducted as part of VJS's PhD thesis and does not necessarily represent the opinions or official position of Alberta Environment and Parks. This paper is a contribution of the Qu'Appelle Long-term Ecological Research program (QU-LTER). We gratefully acknowledge that this research took place on Treaty 4 territory, homelands of the Cree, Saulteaux, Dakota, Nakota, Lakota and Metis peoples.

Author contributions VJS and PRL designed the study: VJS lead data collection and performed most analyses; NTB completed GAM analysis; VJS wrote the first version of the manuscript; All authors edited the manuscript and approved the final version.

Data availability The data that support the findings of this study are available from the corresponding author upon reasonable request.

Code availability $R$ code used in generalized additive models available from NTB on request.

\section{Declarations}

Conflict of interest The authors declare no conflict of interest.

Open Access This article is licensed under a Creative Commons Attribution 4.0 International License, which permits use, sharing, adaptation, distribution and reproduction in any medium or format, as long as you give appropriate credit to the original author(s) and the source, provide a link to the Creative Commons licence, and indicate if changes were made. The images or other third party material in this article are included in the article's Creative Commons licence, unless indicated otherwise in a credit line to the material. If material is not included in the article's Creative Commons licence and your intended use is not permitted by statutory regulation or exceeds the permitted use, you will need to obtain permission directly from the copyright holder. To view a copy of this licence, visit http://creativecommons.org/licenses/by/4.0/.

\section{References}

APHA-AWWA/WEF (1998) Standard methods for the examination of water and wastewater, 20th edn. American Public Health Association, Washington DC, USA

Agriculture Canada (1982) Growing and managing alfalfa in Canada. Cat. No. A53-1704/1982E. Government of Canada, Minister of Supply and Services, Ottawa, Canada

Agriculture and Agri-Food Canada (2008) Watershed Boundaries of the Prairie Farm Rehabilitation Administration Project. https://www4.agr.gc.ca/AAFC-AAC/displayafficher.do?id=1228407260356\&lang=eng. Accessed May 2014

Agriculture and Agri-Food Canada (AAFC) (2013) Annual crop inventory. https://open.canada.ca/data/en/dataset/ ba2645d5-4458-414d-b196-6303ac06c1c9. Accessed June 2017

Alberta Agriculture and Forestry (2011) Irrigation scheduling for spring wheat in southern Alberta-Agdex 112/561-2

Alberta Agricultural and Rural Development (2013) Wheat nutrient and fertilizer requirements: nitrogen. https:// www1.agric.gov.ab.ca/\$department/deptdocs.nsf/all/ crop1273. Accessed May 2017

Anderson DM et al (2008) Harmful algal blooms and eutrophication: examining linkages from selected coastal regions of the United States. Harmful Alg 8:39-53. https://doi.org/ 10.1016/j.hal.2008.08.017

Belisle BS, Steffen MM, Pound HL, Watson SB, DeBruyn JM, Bourbonniere RA, Boyer JL, Wilhelm SW (2016) Urea in Lake Erie: organic nutrient sources as potentially important drivers of phytoplankton biomass. J Great Lakes Res 42:599-607. https://doi.org/10.1016/j.jglr.2016.03.002

Bergbusch NT (2020) The Impact of a Nitrogen-removal Wastewater Upgrade on Primary Producers in Phosphorous-rich Streams of the Northern Great Plains. MSc Thesis, University of Regina, Regina, Saskatchewan Canada

Berman T (2001) The role of DON and the effect of N: P ratios on occurrence of cyanobacterial blooms: implications from the outgrowth of Aphanizomenon in Lake Kinneret. Limnol Oceanogr 46:443-447. https://doi.org/10.4319/lo.2001.46. 2.0443

Berman T, Bronk DA (2003) Dissolved organic nitrogen: a dynamic participant in aquatic ecosystems. Aquat Microb Ecol 31:279-305. https://doi.org/10.3354/ame031279

Bernot MJ, Dodds WK (2005) Nitrogen retention, removal, and saturation in lotic ecosystems. Ecosystems 8:442-453. https://doi.org/10.1007/s10021-003-0143-y

Bogard MJ, Donald DB, Finlay K, Leavitt PR (2012) Distribution and regulation of urea in lakes of central North America. Freshw Biol 57:1277-1292. https://doi.org/10. 1111/j.1365-2427.2012.02775.x

Bogard MJ, Vogt RJ, Hayes NM, Leavitt PR (2020) Unabated nitrogen pollution favours growth of toxic cyanobacteria over chlorophytes in most hypereutrophic lakes. Environ Sci Technol 54:3219-3227. https://doi.org/10.1021/acs. est.9b06299

Bronk DA et al (2010) Effluent organic nitrogen (EON): bioavailability and photochemical and salinity-mediated 
release. Environ Sci Technol 44:5830-5835. https://doi. org/10.1021/es101115g

Bronk DA, See JH, Bradley P, Killberg L (2007) DON as a source of bioavailable nitrogen for phytoplankton. Biogeosciences 4:283-296. https://doi.org/10.5194/bg-4-2832007

Brookshire ENJ, Valett HM, Thomas SA, Webster JR (2005) Coupled cycling of dissolved organic nitrogen and carbon in a forest stream. Ecology 86:2487-2496. https://doi.org/ 10.1890/04-1184

Buchanan TJ, Somers WP (1976) Discharge measurements at gauging stations. In: techniques of water-resources investigations of the United States Geological Survey-Book 3: applications of hydraulics. United States Government Printing Office. p. 71

Bushaw KL, Zepp RG, Tarr MA, Schulz-Jander D, Miller WL, Bronk DA, Moran MA (1996) Photochemical release of biologically available nitrogen from aquatic dissolved organic matter. Nature 381:404-407. https://doi.org/10. $1038 / 381404 \mathrm{a} 0$

Cade-Menun BJ, Bell G, Baker-Ismail S, Fouli Y, Hodder KR, McMartin DW, Perez-Valdivia C, Wu K (2013) Nutrient loss from Saskatchewan cropland and pasture in spring snowmelt runoff. Can J Soil Sci 93:445-458. https://doi. org/10.4141/cjss2012-042

Canadian Council of Ministers of the Environment (CCME). 2010. Canadian water quality guidelines for the protection of aquatic life-Ammonia. In: Canadian environmental quality guidelines, Canadian Council of Ministers of the the Environment, Winnipeg

Canadian Council of Ministers of the Environment (CCME). 2012. Canadian water quality guidelines for the protection of aquatic life - Nitrate. In: Canadian environmental quality guidelines, Canadian Council of Ministers of the the Environment, Winnipeg

Chambers PA, Benoy GA, Brua RB, Culp JM (2011) Application of nitrogen and phosphorus criteria for streams in agricultural landscapes. Water Sci Technol 64:2185-2191. https://doi.org/10.2166/wst.2011.760

Cho BC, Park MG, Shim JH, Azam F (1996) Significance of bacteria in urea dynamics in coastal surface waters. Marine Ecol Prog Ser 142:19-26. https://doi.org/10.3354/ meps142019

Corriveau JP, Chambers PA, Culp JM (2013) Seasonal variation in nutrient export along streams in the Northern Great Plains. Water Air Soil Pollut 224:1594. https://doi.org/10. 1007/s11270-013-1594-1

Cozzi S, Mistaro A, Sparnocchia S, Colugnati L, Bajt O, Toniatti L (2014) Anthropogenic loads and biogeochemical role of urea in the Gulf of Trieste. Sci Total Environ 493:271-281. https://doi.org/10.1016/j.scitotenv.2014.05. 148

Davies H, Hanley PT (2010) 2010 State of the watershed report. Saskatchewan Watershed Authority. Government of Saskatchewan, Regina, Saskatchewan. pp. 39

Davis AM, Tink M, Rohde K, Brodie JE (2016) Urea contributions to dissolved "organic" nitrogen losses from intensive, fertilised agriculture. Agric Ecosyst Environ 223:190-196. https://doi.org/10.1016/j.agee.2016.03.006

del Giorgio PA, Pace ML (2008) Relative independence of dissolved organic carbon transport and processing in a large temperate river: the Hudson River as both pipe and reactor. Limnol Oceanogr 53:185-197

di Bonito M, Breward N, Crout N, Smith N, Young S (2008) Overview of selected soil pore water extraction methods for the determination of potentially toxic elements in contaminated soils: operational and technical aspects. In: De Vivo B, Belkin HE, Lima A (eds) Environmental geochemistry: site characterization data analysis and case histories. Elsevier, Amsterdam, pp 213-249

Donald DB, Bogard MJ, Finlay K, Leavitt PR (2011) Comparative effects of urea, ammonium, and nitrate on phytoplankton abundance, community composition, and toxicity in hypereutrophic freshwaters. Limnol Oceanogr 56:2161-2175. https://doi.org/10.4319/lo.2011.56.6.2161

Dumanski S, Pomeroy JW, Westbrook CJ (2015) Hydrological regime changes in a Canadian Prairie basin. Hydrol Process 29:3893-3904. https://doi.org/10.1002/hyp.10567

Dylla NP (2019) Downstream effects on denitrification and nitrous oxide from an advanced wastewater treatment plant upgrade. MSc thesis. University of Saskatchewan, Saskatoon, Canada. pp. 124

Fang X, Minke A, Pomeroy JW, Brown T, Westbrook C, Guo X, Guangul S (2007) A review of Canadian Prairie hydrology: Principles, modelling and response to land use and drainage change. University of Saskatchewan Centre for Hydrology Report \#2, University of Saskatchewan, Saskatoon, Canada

Finlay K, Leavitt PR, Wissel B, Prairie YT (2009) Regulation of spatial and temporal variability of carbon flux in six hardwater lakes of the northern Great Plains. Limnol Oceanogr 54:2553-2564. https://doi.org/10.4319/lo.2009.54.6_part_ 2.2553

Finlay K, Patoine A, Donald DB, Bogard MJ, Leavitt PR (2010) Experimental evidence that pollution with urea can degrade water quality in phosphorus-rich lakes of the Northern Great Plains. Limnol Oceanogr 55:1213-1230. https://doi.org/10.4319/lo.2010.55.3.1213

Food and Agriculture Organization of the United Nations (2002) World agriculture towards 2015/2030: Summary report. Food and Agriculture Organization of the United Nations, 97 pp. Available at http://www.fao.org/docrep/004/ Y3557E/Y3557E00.HTM. Accessed March 2017

Ghosh S, Leff LG (2013) Impacts of labile organic carbon concentration on organic and inorganic nitrogen utilization by a stream biofilm bacterial community. Appl Environ Microbiol 79:7130-7141. https://doi.org/10.1128/AEM. 01694-13

Gianfagna CC, Johnson CE, Chandler DG, Hofmann C (2015) Watershed area ratio accurately predicts daily streamflow in nested catchments in the Catskills, New York. J Hydrol 4:583-594. https://doi.org/10.1016/j.ejrh.2015.09.002

Glibert PM, Harrison J, Heil C, Seitzinger S (2006) Escalating worldwide use of urea-a global change contributing to coastal eutrophication. Biogeochemistry 77:441-463. https://doi.org/10.1007/s10533-005-3070-5

Glibert PM, Trice MT, Michael B, Lane L (2005) Urea in the tributaries of the Chesapeake and coastal bays of Maryland. Water Air Soil Pollut 160:229-243. https://doi.org/10. 1007/s11270-005-2546-1

Haig HA, Hayes NM, Simpson GL, Yi Y, Wissel B, Hodder KR, Leavitt PR (2020) Comparison of isotopic mass balance 
and instrumental techniques as estimates of basin hydrology in seven connected lakes over 12 years. J Hydrol X 6:100046. https://doi.org/10.1016/j.hydroa.2019.100046

Hall RI, Leavitt PR, Quinlan R, Dixit AS, Smol JP (1999) Effects of agriculture, urbanization, and climate on water quality in the northern Great Plains. Limnol Oceanogr 44:739-756. https://doi.org/10.4319/lo.1999.44.3_part_2. 0739

Han K, Kleinman PJA, Saporito LS, Church C, McGrath JM, Reiter MS, Tingle SC, Allen AL, Wang LQ, Bryant RB (2015) Phosphorus and nitrogen leaching before and after tillage and urea application. J Environ Qual 44:560-571. https://doi.org/10.2134/jeq2014.08.0326

Han X, Zhu ZG, Xu H, Wilhelm SW, Qin B, Li Z (2014) Source analysis of urea-N in Lake Taihu during summer. Environ Sci 35:2547-2556

Heathwaite AL, Johnes PJ (1996) Contribution of nitrogen species and phosphorus fractions to stream water quality in agricultural catchments. Hydrol Process 10:971-983. https://doi.org/10.1002/(SICI)1099-1085(199607)10:7\% 3c971::AID-HYP351\%3e3.0.CO;2-N

Heinz M, Graeber D, Zak D, Zwirnmann E, Gelbrecht J, Pusch MT (2015) Comparison of organic matter composition in agricultural versus forest affected headwaters with special emphasis on organic nitrogen. Environ Sci Technol 49:2081-2090. https://doi.org/10.1021/es505146h

Jackson M (2016) Phytoplankton and nutrient dynamics with a focus on nitrogen form in the Anacostia River, in Washington, D. C. and West Lake, in Hangzhou, China. M.Sc. thesis. University of Maryland

Jeffrey SW, Humphrey GF (1975) New spectrophotometric equations for determining chlorophylls a, b, c1 and c2 in higher plants, algae, and natural phytoplankton. Biochem Physiol Pflanzn 167:191-194

Johnson LT et al (2013) Quantifying the production of dissolved organic nitrogen in headwater streams using $15 \mathrm{~N}$ tracer additions. Limnol Oceanogr 58:1271-1285. https://doi. org/10.4319/lo.2013.58.4.1271

Johnson LT, Tank JL, Arango CP (2009) The effect of land use on dissolved organic carbon and nitrogen uptake in streams. Freshw Biol 54:2335-2350. https://doi.org/10. $1111 / \mathrm{j} .1365-2427.2009 .02261 . x$

Jørgensen NOG (2006) Uptake of urea by estuarine bacteria. Aquat Microb Ecol 42:227-242. https://doi.org/10.3354/ ame042227

Kaushal SS, Delaney-Newcomb K, Findlay SEG, Newcomer TA, Duan S, Pennino MJ, Sivirichi JM, Sides-Raley AM, Walbridge MR, Belt KT (2014) Longitudinal patterns in carbon and nitrogen fluxes and stream metabolism along an urban watershed continuum. Biogeochemistry 121:23-44. https://doi.org/10.1007/s10533-014-9979-9

Kemp MJ, Dodds WK (2001) Spatial and temporal patterns of nitrogen concentrations in pristine and prairie streams. Biogeochemistry 53:125-141. https://doi.org/10.1023/A: 1010707632340

Kibet LC, Bryant RB, Buda AR, Kleinman PJA, Saporito LS, Allen AL, Hashem FM, May EB (2016) Persistence and surface transport of urea-nitrogen: a rainfall simulation study. J Environ Qual 45:1062-1070. https://doi.org/10. 2134/jeq2015.09.0495
King MD, Bryant RB, Saporito LS, Buda AR, Allen AL, Hughes LA, Hashem FM, Kleinman PJA, May EB (2017) Urea release by intermittently saturated sediments from a coastal agricultural landscape. J Environ Qual 46:302-310. https:// doi.org/10.2134/jeq2016.08.0304

Korth F, Deutsch B, Liskow I, Voss M (2012) Uptake of dissolved organic nitrogen by size-fractionated plankton along a salinity gradient from the North Sea to the Baltic Sea. Biogeochemistry 111:347-360. https://doi.org/10. 1007/s10533-011-9656-1

Krausfeldt LE, Farmer AT, Castro Gonzalez HF, Zepernick BN, Campagna SR, Wilhelm SW (2019) Urea is both a carbon and nitrogen source for Microcystis aeruginosa: tracking ${ }^{13} \mathrm{C}$ incorporation at bloom $\mathrm{pH}$ conditions. Front Microbiol 10:01064. https://doi.org/10.3389/fmicb.2019.01064

L'Helguen S, Slawyk G, Le Corre P (2005) Seasonal patterns of urea regeneration by size-fractionated microheterotrophs in well-mixed temperate coastal waters. J Plankt Res 27:263-270. https://doi.org/10.1093/plankt/fbh174

Leavitt PR, Brock CS, Ebel C, Patoine A (2006) Landscapescale effects of urban nitrogen on a chain of freshwater lakes in central North America. Limnol Oceanogr 51:2262-2277. https://doi.org/10.4319/lo.2006.51.5.2262

Leavitt PR, Hodgson DA (2001) Sedimentary pigments. In: Smol JP, Birks HJB, Last WM (eds) Tracking environmental change using lake sediments: terrestrial, algal and siliceous indicators, vol 3. Kluwer, Alphen aan den Rijn, pp 295-325

Lomas MW, Trice TM, Glibert PM, Bronk DA, McCarthy JJ (2002) Temporal and spatial dynamics of urea uptake and regeneration rates and concentrations in Chesapeake Bay. Estuar Coasts 25:469-482. https://doi.org/10.1007/ BF02695988

Lorite-Herrera M, Hiscock K, Jiménez-Espinosa R (2009) Distribution of dissolved inorganic and organic nitrogen in river water and groundwater in an agriculturally-dominated catchment, south-east Spain. Water Air Soil Pollut 198:335-346. https://doi.org/10.1007/s11270-008-9849-y

Lutz BD, Bernhardt ES, Roberts BJ, Mulholland PJ (2011) Examining the coupling of carbon and nitrogen cycles in Appalachian streams: the role of dissolved organic nitrogen. Ecology 92:720-732. https://doi.org/10.1890/100899.1

Malhi S, Oliver E, Mayerle G, Kruger G, Gill KS (2003) Improving effectiveness of seedrow-placed urea with urease inhibitor and polymer coating for durum wheat and canola. Comm Soil Sci Plant Anal 34:1709-1727. https:// doi.org/10.1081/CSS-120021307

Marra G, Wood SN (2011) Practical variable selection for generalized additive models. Comput Stat Data Anal 55:2372-2387. https://doi.org/10.1016/j.csda.2011.02.004

Martin RA, Harrison JA (2011) Effect of high flow events on instream dissolved organic nitrogen concentration. Ecosystems 14:1328-1338. https://doi.org/10.1007/s10021-0119483-1

McKenzie RH, Kryzanowski L, Pauly D (2004) Alberta fertilizer guide-Agdex 54-1. Alberta Agriculture \& Rural Development.

Miki A (2015) Wascana Creek riparian health assessment project final report 2015. Prepared for the Wascana Upper Qu'Appelle Watersheds Association. http://wuqwatr.ca/ 
+pub/Minutes/Pictures/WRHA\%20PHASE $\% 204 \%$

20Final\%20Report\%202015\%20Aug\%2027\%20FINAL. pdf. Accessed June 2017

Millennium Ecosystem Assessment (2005) Ecosystems and human well-being: current state and trends: findings of the condition and trends working group (Millennium Ecosystem Assessment Series). Isl Press. https://doi.org/10.1007/ 978-90-481-9659-3_81

Mitamura O, Cho KS, Hong SU (1994) Urea decomposition associated with the activity of microorganisms in surface waters of the North Han River, Korea. Archiv Hydrobiol 131:231-242

Mitamura O, Ishida N, Seike Y, Kondo K, Okumura M (2000) Diel variation in urea decomposing activity in the euphotic zone of brackish Lake Nakaumi. Limnology 1:151-157. https://doi.org/10.1007/s102010070001

Mitamura O, Nakamoto N, Ibañez MSR, Cavalcant PRS, Neto JPC, Barbieri R (2012) Biogeochemical cycling of urea in the aquatic systems of Pindaré and Turiaçu River basins, a pre-Amazonian floodplain, Baixada Maranhense, Brazil. Acta Limnol Bras 24:167-180

Mitamura O, Saijo Y (1980) In situ measurement of the urea decomposition rate and its turnover rate in the Pacific Ocean. Mar Biol 58:147-152. https://doi.org/10.1007/ BF00396126

Mowchenko M, Meid PO (1983). The determination of gross and effective drainage areas in the Prairie Provinces. Hydrology report \#104. Prairie Farm Rehabilitation Administration, Engineering Branch, Regina, Saskatchewan.

Mulholland PJ (1992) Regulation of nutrient concentrations in a temperate forest stream: roles of upland, riparian, and instream processes. Limnol Oceanogr 37:1512-1526. https://doi.org/10.4319/lo.1992.37.7.1512

Mulholland PJ, Tank JL, Sanzone DM, Wollheim MW, Peterson BJ, Webster JR, Meyer JL (2000) Nitrogen cycling in a forest stream determined by a $15 \mathrm{~N}$ tracer addition. Ecol Monogr 70:471-493. https://doi.org/10.1890/00129615(2000)070[0471:NCIAFS]2.0.CO;2

Natural Resources Canada (2016) CanVec. http://open.canada. ca/data/en/dataset/23387971-b6d3-4ded-a40b-

c8e832b4ea08. Accessed June 2017

Olson-Rutz K, Jones C, Pareira Dinkins C (2009) Enhanced efficiency fertilizers. Report EBO188. Montana State University

Park MG, Shim JH, Cho BC (1997) Urea decomposition activities in an ammonium enriched freshwater pond. Aquat Microb Ecol 13:303-311. https://doi.org/10.3354/ ame 013303

Pedersen EJ, Miller DL, Simpson GL, Ross N (2019) Hierarchical generalized additive models in ecology: an introduction with mgcv. PeerJ 7:e6876. https://doi.org/10.7717/ peerj. 6876

Pellerin BA, Kaushal SS, McDowell WH (2006) Does anthropogenic nitrogen enrichment increase organic nitrogen concentrations in runoff from forested and human-dominated watersheds? Ecosystems 9:852-864. https://doi.org/ 10.1007/s10021-006-0076-3

Pennino MJ, Kaushal SS, Murthy SN, Blomquist JD, Cornwell JC, Harris LA (2016) Sources and transformations of anthropogenic nitrogen along an urban river-estuarine continuum. Biogeosciences 13:6211-6228. https://doi.org/ 10.5194/bg-13-6211-2016

Petersen S, Roslev P, Bol R (2004) Dynamics of a pasture soil microbial community after deposition of cattle urea amended with [C-13] urea. Appl Environ Microbiol 70:6363-6369. https://doi.org/10.1128/AEM.70.11.63636369.2004

Peterson BJ et al (2001) Control of nitrogen export from watersheds by headwater streams. Science 292:86-90. https://doi.org/10.1126/science.1056874

Pham SV, Leavitt PR, McGowan S, Wissel B, Wassenaar LI (2009) Spatial and temporal variability of prairie lake hydrology as revealed using stable isotopes of hydrogen and oxygen. Limnol Oceanogr 54:101-118. https://doi.org/ 10.4319/lo.2009.54.1.0101

Pomeroy J, Gray D, Brown T, Hedstrom N, Quinton W, Granger R, Carey S (2007) The cold regions hydrological model: a platform for basing process representation and model structure on physical evidence. Hydrol Process 21:2650-2667. https://doi.org/10.1002/hyp.6787

Przednowek DWA, Entz MH, Irvine B, Flaten DN, Thiessen Martens JR (2004) Rotational yield and apparent N benefits of grain legumes in southern Manitoba. Can J Plant Sci 84:1093-1096. https://doi.org/10.4141/P04-032

R Core Team (2019) R: a language and environment for statistical computing. Retrieved from https://www.R-project. org/

Rattan KJ, Corriveau JC, Brua RB, Culp JM, Yates AG, Chambers PA (2017) Quantifying seasonal variation in total phosphorus and nitrogen from prairie streams in the Red River Basin, Manitoba Canada. Sci Tot Environ 575:649-659. https://doi.org/10.1016/j.scitotenv.2016.09. 073

Remsen CC, Carpenter EJ, Schroeder BW (1972) Competition for urea among estuarine microorganisms. Ecology 53:921-926. https://doi.org/10.2307/1934309

Revilla M, Alexander J, Glibert PM (2005) Urea analysis in coastal waters: comparison of enzymatic and direct methods. Limnol Oceanogr Meth 3:290-299. https://doi.org/10. 4319/lom.2005.3.290

Scott D, Harvey J, Alexander R, Schwarz G (2007) Dominance of organic nitrogen from headwater streams to large rivers across the conterminous United States. Global Biogeochem Cycles 21:1-8. https://doi.org/10.1029/ 2006GB002730

Seitzinger SP, Sanders RW (1997) Contribution of dissolved organic nitrogen from rivers to estuarine eutrophication. Mar Ecol Prog Ser 159:1-12. https://doi.org/10.3354/ meps 159001

Seitzinger SP, Styles RV, Boyer EW, Alexander RB, Billen G, Howarth RW, Mayer B, Van Breemen N (2002) Nitrogen retention in rivers: model development and application to watersheds in the northeastern U.S.A. Biogeochemistry 57(58):199-237. https://doi.org/10.1023/A: 1015745629794

Siuda W, Chróst RJ (2006) Urea and ureolytic activity in lakes of different trophic status. Polish J Microbiol 55:211-225

Slawyk G, Raimbault P, Garcia N (1998) Measuring gross uptake of $15 \mathrm{~N}$-labeled nitrogen by marine phytoplankton without particulate matter collection: evidence of low $15 \mathrm{~N}$ losses to the dissolved organic nitrogen pool. Limnol 
Oceanogr 43:1734-1739. https://doi.org/10.4319/lo.1998. 43.7.1734

Solomon CM, Collier JL, Berg GM, Glibert PM (2010) Role of urea in microbial metabolism in aquatic systems: a biochemical and molecular review. Aquat Microb Ecol 59:67-88. https://doi.org/10.3354/ame01390

Solomon CM, Glibert PM (2008) Urease activity in five phytoplankton species. Aquat Microb Ecol 52:149-157. https://doi.org/10.3354/ame01213

Stanley EH, Maxted JT (2008) Changes in the dissolved nitrogen pool across land cover gradients in Wisconsin streams. Ecol Appl 18:1579-1590. https://doi.org/10.1890/071379.1

Statistics Canada (2016) Service bulletin-Fertilizer shipments survey. Catalogue no. 21-002-X. http://www5.statcan.gc. ca/olc-cel/olc. action?ObjId=21-022-

X2016003\&ObjType=46\&lang=en. Accessed June 2017.

Stepanauskas R, Laudon H, Jørgensen NOG (2000) High DON bioavailability in boreal streams during a spring flood. Limnol Oceanogr 45:1298-1307. https://doi.org/10.4319/ lo.2000.45.6.1298

Swarbrick VJ, Quiñones-Rivera Z, Leavitt PR (2020) Seasonal variability in effects of urea and phosphorous on phytoplankton abundance and composition in a hypereutrophic hardwater lake. Freshw Biol 65(65):1765-1781. https:// doi.org/10.1111/fwb. 13580

Swarbrick VJ, Simpson GL, Glibert PM, Leavitt PM (2019) Differential stimulation and suppression of phytoplankton growth by ammonium enrichment in eutrophic hardwater lakes over 16 years. Limnol Oceanogr 64:S130-S149. https://doi.org/10.1002/lno.11093

Swensen B, Singh BR (1997) Transport and transformation of urea and its derivatives through a mineral subsoil. J Environ Qual 26:1516-1523. https://doi.org/10.2134/jeq1997. $00472425002600060010 x$

Switzer T (2008) Urea loading from a spring storm-Knysna estuary, South Africa. Harmful Algae 8:66-69. https://doi. org/10.1016/j.hal.2008.08.005

Therkildsen MS, Lomstein BA (1994) Seasonal variation in sediment urea turnover in a shallow estuary. Mar Ecol Prog Ser 109:77-82

Thiessen KH, Flaten DN, Grant CA, Karamanos RE, Entz MH (2005) Efficiency of fall-banded urea for spring wheat production in Manitoba: influence of application date, landscape position and fertilizer additives. Can J Soil Sci 85:649-666. https://doi.org/10.4141/S05-017

Thorén AK (2007) Urea transformation of wetland microbial communities. Microb Ecol 53:221-232. https://doi.org/10. 1007/s00248-006-9098-9

Triska FJ, Duff JH, Avanzino RJ (1990) Influence of exchange flow between the channel and hyporheic zone on nitrate production in a small mountain stream. Can J Fish Aquat Sci 47:2099-2111. https://doi.org/10.1139/f90-235

Tzilkowski SS et al (2018) Urea fluctuations in stream baseflow across land cover gradients and seasons in a coastal plain river system. J Am Water Res Assoc 55:228-246. https:// doi.org/10.1111/1752-1688.12716

Vogt RJ, Sharma S, Leavitt PR (2018) Direct and interactive effects of climate, meteorology, river hydrology, and lake characteristics on water quality in productive lakes of the Canadian Prairies. Can J Fish Aquat Sci 75:47-59. https:// doi.org/10.1139/cjfas-2016-0520

Waiser MJ, Robarts RD (2004) Photodegradation of DOC in a shallow prairie wetland: evidence from seasonal changes in DOC optical properties and chemical characteristics. Biogeochemistry 69:263-284. https://doi.org/10.1023/B: BIOG.0000031048.20050.4e

Waiser MJ, Tumber VJ, Holm J (2011) Effluent-dominated streams. Part 1: presence and effects of excess nitrogen and phosphorus in Wascana Creek, Saskatchewan, Canada. Environ Toxicol Chem 30:496-507. https://doi.org/10. 1002/etc.399

Wickham H (2016) ggplot2: elegant graphics for data analysis. Springer-Verlag, New York

Wiegner TN, Seitzinger SP, Glibert PM, Bronk DA (2006) Bioavailability of dissolved organic nitrogen and carbon from nine rivers in the eastern United States. Aquat Microb Ecol 43:277-287. https://doi.org/10.3354/ame043277

Wiley MJ, Osborne LL, Larimore RW (1990) Longitudinal structure of an agricultural prairie river system and its relationship to current stream ecosystem theory. Can J Fish Aquat Sci 47:373-384. https://doi.org/10.1139/f90-039

Wood SN (2011) Fast stable restricted maximum likelihood and marginal likelihood estimation of semiparametric generalized linear models. J R Stat Soc 73:3-36. https://doi.org/ 10.1111/j.1467-9868.2010.00749.x

Wood SN (2013a) On p-values for smooth components of an extended generalized additive model. Biometrika 100:221-228. https://doi.org/10.1093/biomet/ass048

Wood SN (2013b) A simple test for random effects in regression models. Biometrika 100:1005-1010. https://doi.org/10. 1093/biomet/ast038

Wood SN (2017) Generalized additive models: an introduction with R, 2nd edn. Chapman and Hall/CRC, Boca Raton

Wood SN, Pya N, Säfken B (2016) Smoothing parameter and model selection for general smooth models. J Am Stat Assoc 111:1548-1563. https://doi.org/10.1080/01621459. 2016.1180986

Wymore AS, Rodríguez-Cardona B, McDowell WH (2015) Direct response of dissolved organic nitrogen to nitrate availability in headwater streams. Biogeochemistry 126:1-10. https://doi.org/10.1007/s10533-015-0153-9

Young RG, Huryn AD (1996) Interannual variation in discharge controls ecosystem metabolism along a grassland river continuum. Can J Fish Aquat Sci 53:2199-2211. https:// doi.org/10.1139/cjfas-53-10-2199

Publisher's Note Springer Nature remains neutral with regard to jurisdictional claims in published maps and institutional affiliations. 